\title{
Possibilities for Developing Electromobility by Using Autonomously Powered Trolleybuses Based on the Example of Gdynia
}

\author{
Mikołaj Bartłomiejczyk ${ }^{1, *(D)}$ and Marcin Połom ${ }^{2, *(D)}$ \\ 1 Department of Electrical Engineering of Transport, Faculty of Electrical and Control Engineering, \\ Gdańsk University of Technology, 80-216 Gdańsk, Poland \\ 2 Department of Regional Development Geography, Institute of Geography, University of Gdańsk, \\ 80-309 Gdańsk, Poland \\ * Correspondence: mikolaj.bartlomiejczyk@pg.edu.pl (M.B.); marcin.polom@ug.edu.pl (M.P.)
}

Citation: Bartłomiejczyk, M.; Połom, M. Possibilities for Developing Electromobility by Using Autonomously Powered Trolleybuses Based on the Example of Gdynia. Energies 2021, 14, 2971. https:// doi.org/10.3390/en14102971

Academic Editor: Javier Contreras

Received: 6 May 2021

Accepted: 19 May 2021

Published: 20 May 2021

Publisher's Note: MDPI stays neutral with regard to jurisdictional claims in published maps and institutional affiliations.

Copyright: (c) 2021 by the authors. Licensee MDPI, Basel, Switzerland. This article is an open access article distributed under the terms and conditions of the Creative Commons Attribution (CC BY) license (https:/ / creativecommons.org/licenses/by/ $4.0 /)$.

\begin{abstract}
Trolleybus transport refers to contemporary challenges related to a reduction in emissions of greenhouse gases and $\mathrm{CO}_{2}$ into the atmosphere formulated by international institutions, such as the United Nations, the Organisation for Security and Co-operation in Europe, or the European Union. Departure from fossil fuels in urban transport is one of the key challenges for the coming years. Trolleybuses are an important tool in this task, even though their importance was declining in the past. Nowadays, due to, among others, technological development, in particular the availability of high-capacity batteries, their long life and low weight, trolleybus transport is becoming popular again. The use of the existing overhead contact infrastructure of the trolleybus network and small on-board batteries allow expanding the spatial accessibility of zero-emission public transport. Thus, this reduces the social differentiation in access to environmentally friendly transport that does not emit pollutants at the place of operation. The article presents possibilities of using on-board batteries in shaping trolleybus connections with the optimal use of the existing overhead contact lines (OHL). It presents a procedure that allows for the evaluation of the extent to which the OHL should cover the routes of bus lines in order to qualify for trolleybus service in the In-Motion-Charging (IMC) technology. Analysis of the literature shows inadequate scientific studies on combining the advantages of overhead wiring and the development of on-board battery technology in popularising zero-emission transport. This article addresses the key issues related to the use of partially autonomous trolleybuses.
\end{abstract}

Keywords: electromobility; trolleybus; autonomous vehicle; public transport; battery electric vehicle; electric vehicle; In-Motion Charging

\section{Introduction}

\subsection{Developing Electromobility in Public Transport Systems}

Climate changes taking place in the world have forced technological transformations in transport in the last two decades. This sector of the economy is responsible for a significant proportion of greenhouse gas emissions into the atmosphere [1,2]. It has become a subject of global political actions aimed at decarbonisation through electrification of individual and public transport. The United Nations has taken global action to accelerate the reduction of emissions of $\mathrm{CO}_{2}$ and other harmful substances into the atmosphere [3]. European institutions, including the OECD [4], undertake similar actions against transport emissions. The European Union has passed many legal acts related to pro-ecological transformations in transport and the adoption of the so-called green deal. The main assumptions concern a need to decarbonise transport in cities and completely abandon fossil fuels $[5,6]$. In this in view, an EU directive on alternative fuels was prepared [7].

Polish steps regarding the development of electromobility are a response to global activities, in particular in the European Union. For this purpose, the National framework 
for the policy of development of alternative fuel infrastructure [8] and the Electromobility Development Plan [9-11] were established. There is an unfavourable balance in the Polish energy mix, as most of the electricity produced in Poland comes from burning lignite and hard coal [12]. However, the outlined plan to depart from fossil fuels, as well as to increase the share of green energy, helps allow us to look positively at electrification of means of transport, including urban public transport. The first step will be to improve the condition of the environment in the place where diesel buses are to be replaced with electric ones $[13,14]$. Solutions to popularise electric transport in cities involve replacing diesel buses with those powered by electricity and developing the existing tramway and trolleybus transport systems. Nowadays, thanks to the development of battery technologies especially, trolleybuses are an important tool in shaping sustainable and environmentally friendly urban transport [15]. Owing to the potential use of the existing infrastructure of overhead contact systems, it is possible to reduce the size (weight and capacity) of on-board batteries and thus to improve the indicators of economic efficiency. Trolleybuses have several competitive advantages over electric buses that are particularly important in the balance of the entire life cycle of a vehicle [16].

\subsection{Scientific Background of the Trolleybus Transport Research}

Electric public transport is an important research issue. Due to the above-mentioned climate changes, it has become a subject of political actions but also of scientific considerations. Among the basic means of urban transport, trolleybuses are the least popular as a research issue. This is probably due to the number of active trolleybus systems around the world, currently not exceeding $300[17,18]$. In view of technological development, in particular concerning auxiliary power systems, trolleybuses are gaining in popularity, and many cities consider introducing them to public transport. Currently, work in this area is conducted in many European cities, e.g., in Berlin [19], Iasi [15], Pescara [20], Prague [21,22], and Nashik in India [23].

Scientific research on trolleybus transport in particular involves case studies on specific issues related to various aspects of operation. The latest scientific reports have been collected and systematised in Table 1.

The literature analysis allowed for the identification of the dominant issues, namely the transport policy and the use of battery power systems. Based on the literature review, it can be concluded that there is a research gap as regards the possibility of using the existing infrastructure of trolleybus overhead contact system and linking it to the advantages of modern battery technologies in the field of spatial development of connections.

Table 1. Identification of research issues in the field of trolleybus transport (source: own elaboration).

\begin{tabular}{|c|c|c|}
\hline Subject & Detailed Issue & Source \\
\hline \multirow{4}{*}{ Auxiliary power sources } & Battery & $\begin{array}{l}\text { Alfieri et al. [24]; Bartłomiejczyk [25]; Bartłomiejczyk, } \\
\text { Połom [26]; Bartłomiejczyk, Połom [27]; } \\
\text { Berckmans et al. [28]; Berigk et al. [29]; Gao et al. [30]; } \\
\text { Lenz [31]; Połom, Bartłomiejczyk [32]; Rogge et al. [33]; } \\
\text { Wołek et al. [34] }\end{array}$ \\
\hline & Diesel unit & Połom, Bartłomiejczyk [32] \\
\hline & Supercapacitor & Połom, Bartłomiejczyk [32] \\
\hline & $\begin{array}{l}\text { Financial efficiency of using auxiliary } \\
\text { power sources }\end{array}$ & Hołyszko, Filipek [35]; Jeong et al. [36] \\
\hline \multirow[b]{2}{*}{ Environmental impact } & Environmental challenges & Santos [1]; Zhang, Fujimori [2] \\
\hline & $\begin{array}{l}\text { Holistic studies of the environmental } \\
\text { impact of electric public transport }\end{array}$ & Pietrzak, Pietrzak [37]; Yusof et al. [38] \\
\hline
\end{tabular}


Table 1. Cont.

\begin{tabular}{|c|c|c|}
\hline Subject & Detailed Issue & Source \\
\hline \multirow{2}{*}{ Financial cost } & Life cycle operating costs & $\begin{array}{l}\text { Klucininkas et al. [39]; Lajunen [40]; Potkány et al. [41]; } \\
\text { Sheth, Sarkar [42] }\end{array}$ \\
\hline & Operating costs & $\begin{array}{l}\text { Czermański [43]; Czermański [44]; Dębicka, } \\
\text { Czermański [45]; Pietrzak, Pietrzak [46] }\end{array}$ \\
\hline \multirow{2}{*}{ Infrastructure } & Depot & Jarzmik [47] \\
\hline & Power system & Bartłomiejczyk, Połom [48] \\
\hline \multirow{3}{*}{$\begin{array}{l}\text { Manufacture of } \\
\text { trolleybuses }\end{array}$} & $\begin{array}{l}\text { Conversion of a diesel bus into } \\
\text { a trolleybus }\end{array}$ & Bartłomiejczyk et al. [49] \\
\hline & Production of new vehicles & Taczanowski et al. [50] \\
\hline & Trolleybus rolling stock market & Połom, Turżański [51]; Połom et al. [52]; Połom [53] \\
\hline \multirow{5}{*}{$\begin{array}{l}\text { Organisation of trolleybus } \\
\text { transport }\end{array}$} & $\begin{array}{c}\text { Comparative studies of various means of } \\
\text { transport }\end{array}$ & $\begin{array}{l}\text { Bedell [54]; Brdulak et al. [55]; Krawiec et al. [56]; } \\
\text { Kühne [57] }\end{array}$ \\
\hline & Designing new lines & $\begin{array}{l}\text { Bogusławski [58]; Brunton [59]; Göhlich et al. [60]; } \\
\text { Tsolas [61], Wołek et al. [16] }\end{array}$ \\
\hline & $\begin{array}{l}\text { Modernisation of infrastructure and } \\
\text { rolling stock }\end{array}$ & Borowik, Cywiński [62]; Połom [63] \\
\hline & Social research & Hebel [64]; Jagiełło, Gałka [65] \\
\hline & Transport policy & $\begin{array}{l}\text { Biresselioglu et al. [66]; Cansino et al. [67]; } \\
\text { Chertkovskaya, Paulsson [68]; Costa, Fernandes [17]; } \\
\text { Dyr [69], Khorovitch [70], Kołoś, Taczanowski [71], } \\
\text { Krawiec, Krawiec [72], Lejda et al. [73], Mathieu [74], } \\
\text { Pejšova [75], Perujo et al. [76], Petkov [77], Połom [78], } \\
\text { Połom, Wiśniewski [15], Rădulescu et al. [79], } \\
\text { Tomaszewski [12], Tucki et al. [80], Wołek [81] }\end{array}$ \\
\hline \multirow[b]{2}{*}{ Technical aspects } & Drive & Brazis et al. [82]; Hutyria et al. [83] \\
\hline & $\begin{array}{l}\text { Technical conditions for designing } \\
\text { connections in electric public transport }\end{array}$ & Krawiec [84], Molecki [85], Paul, Yamada [86] \\
\hline
\end{tabular}

\subsection{The Idea of Autonomous Trolleybuses}

Trolleybus transport dependent on power from the overhead line (OHL) is often assessed as burdensome in operation. It generates additional costs related to a need to maintain backup diesel buses and limits the possibility of shaping connections flexibly [78]. Therefore, solutions were sought to increase the flexibility of trolleybuses. Owing to the development of technology, alternative methods of powering the trolleybus drive system have emerged, namely internal combustion units functioning as generators, high-capacity batteries, or supercapacitors [32]. Drawing carriers' attention to the improvement in operating conditions, first of all was based on the premise of the high costs of maintaining the bus reserve for the possible loss of power in OHL, serious failure of overhead lines, or long-term renovation or reconstruction of the street. Trolleybuses remaining in the depot did not earn for their maintenance, and buses running on trolleybus lines generated higher costs, which made trolleybus transport look bad in the economic balance sheet. Due to the lack of emissions in the place of operation, the battery drive was of particular importance and hence it rapidly developed [34].

Traction batteries are available in various technologies and are usually dedicated individually to each operator. In Europe, lead, nickel-metal hydride, and nickel-cadmium batteries remain in regular operation, and in recent years lithium technologies (e.g., lithiumion, lithium-polymer, lithium-titanium) have been developed [28,30,33,38]. Looking at the advantages of batteries, their non-emission characteristics should be distinguished in 
contrast to diesel units. A battery-powered trolleybus is still a $100 \%$ electric vehicle, which is particularly important for companies that exclusively operate electrically powered vehicles. The use of diesel aggregates is burdensome in depots not adapted to servicing such vehicles. In the case of batteries, this aspect is nonexistent. As regards the disadvantages, the most marked one is the limited range. Depending on the traction battery capacity, a trolleybus can cover a specific section of the road. The battery capacity translates into its mass, and this, with the size comparable to the mass of a $100 \mathrm{~kW}$ diesel engine, 10 years ago allowed covering from 3 to $7 \mathrm{~km}$ depending on the applied technology [32]. Nowadays, the length of such a section with the same battery mass has increased several times. The service life of the battery cells has also increased. Considering that the battery is a "renewable" power source-it can be recharged from OHL during the normal operation of the trolleybus-its disadvantage in terms of the operating range compared to the diesel generator has been offset. Apart from the aspect of battery capacity and weight, the service life of this power source is also vital. Depending on the used technology and the operation of the batteries (the degree of their discharge), one can estimate their lifetime. For the carrier, it is essential that the factory-implemented solution could be used as long as possible [39-42].

In the last few years, there has been a noticeable increase in interest in electric buses. Currently, most bus manufacturers offer electric vehicles. The number of cities operating test or fully functional bus lines with electric buses is increasing [15]. One can expect that the share of electric buses in urban transport services will be increasing. This trend is in line with the policy adopted by the European Union for mobility in cities, where the share of electric transport is supposed to grow $[55,66,67,80]$.

The development of battery technologies has enabled expanding the driving range of an electric bus between individual charging sessions. Technological progress has also contributed to the reduction of energy consumption by the vehicle; therefore, it is possible to reduce the required capacity of electric batteries. However, charging such a vehicle is still problematic; it is possible by using the following options:

1. charging at night — the bus runs all day without recharging;

2. main charging at night, one-time recharging during the day;

3. using a plug-in system: an electric bus is recharged many times a day, usually when the bus is at the terminus or at bus stops [87].

Battery technologies currently available on the market allow the electric bus to cover a route with a length of approx. $200 \mathrm{~km}$ with heating or air conditioning turned on. Taking into account the average daily transport performance in urban conditions, this value is insufficient if a reserve of power supply should be maintained for a journey in the event of traffic problems $[60,74,76]$. Therefore, the first option is unacceptable in practical operating conditions. The second option requires a break for recharging the battery during the day. This is possible with vehicles that handle peak tasks. However, most of the transport activity in public transport takes the form of all-day shifts, in which it is not possible to exclude a vehicle from traffic. Thus, recharging necessitates providing additional rolling stock reserve for the downtime, which results in a need for a larger number of vehicles than in the case of bus transport, and this generates higher operating costs. The third option-plug-in-seems to be the most promising solution for electric buses. However, as in the case of the second option, it is necessary to exclude the vehicle from traffic for the time of charging. Thus, the possibility of using the vehicle is significantly limited. When the bus is charged, it is excluded from traffic, which again necessitates providing a greater number of vehicles than to serve the same line with diesel vehicles [24,57].

A combination of the advantages of electric buses and trolleybuses answers the public transport needs and at the same time is related to the zero-emission policy of urban transport. Trolleybuses equipped with batteries recharged in motion while powered by the trolleybus overhead line (IMC trolleybuses - in motion charging) are an intermediate solution between these two types of vehicles $[16,25,27,29,34]$. In this case, the sections of routes equipped with OHL common to the transport system are of particular importance. Trolleybuses covering the central sections of routes (e.g., located in the centre) and powered 
from the OHL can move in peripheral areas of the city without the need to build an OHL infrastructure. It is an economically viable solution which simultaneously allows for a significant increase in the share of electric, non-emission transport in the overall urban transport service.

The technology of using the trolleybus network for dynamic vehicle charging was first introduced in 2014 in Landskrona (Sweden). It enabled serving a bus line with batteryoperated trolleybuses, with only $35 \%$ of the route length covered with the overhead contact network [26]. The further development of the IMC technology allows for shortening of the required length of the OHL to $25-30 \%$ of the route length [16,31]. In addition, placing a charging station at the terminus allows for occasional recharging of the vehicle's battery, thus increasing the driving range with autonomous powering. This solution has been used in Solingen (Germany), where trolleybuses were introduced in 2019 to operate route 695. This line runs under the overhead contact line only for $25 \%$ of the route, but the combination of in-motion fast battery charging with additional stationary charging enables service with articulated vehicles (Figure 1). Currently, in Gdynia, as part of the CAR project (Creating Automotive Renewal), a prototype charging station for trolleybuses is being tested. Its power of $150 \mathrm{~kW}$ is a value similar to the charging power used in fast charging stations for electric buses (Figure 2).

\subsection{Arguments in Favour of Developing Public Transport with the Use of Partially Autonomous Trolleybuses}

The costs of setting up a trolleybus system exceed the investment value connected with electric buses; however, when analysing future maintenance costs, the situation may be different. The development of on-board battery technology has contributed to the popularisation of electric buses, but it has also changed the perception of trolleybuses. Thanks to the installation of on-board batteries that are small in size and weight yet with relatively low energy capacity, trolleybuses can now detour road obstacles and flexibly shape connection routes in the event of failures, collisions, road closure to traffic due to renovation, etc. In addition, an autonomous power source allows for the expansion of the spatial availability of zero-emission vehicles without a need to build a power infrastructure.

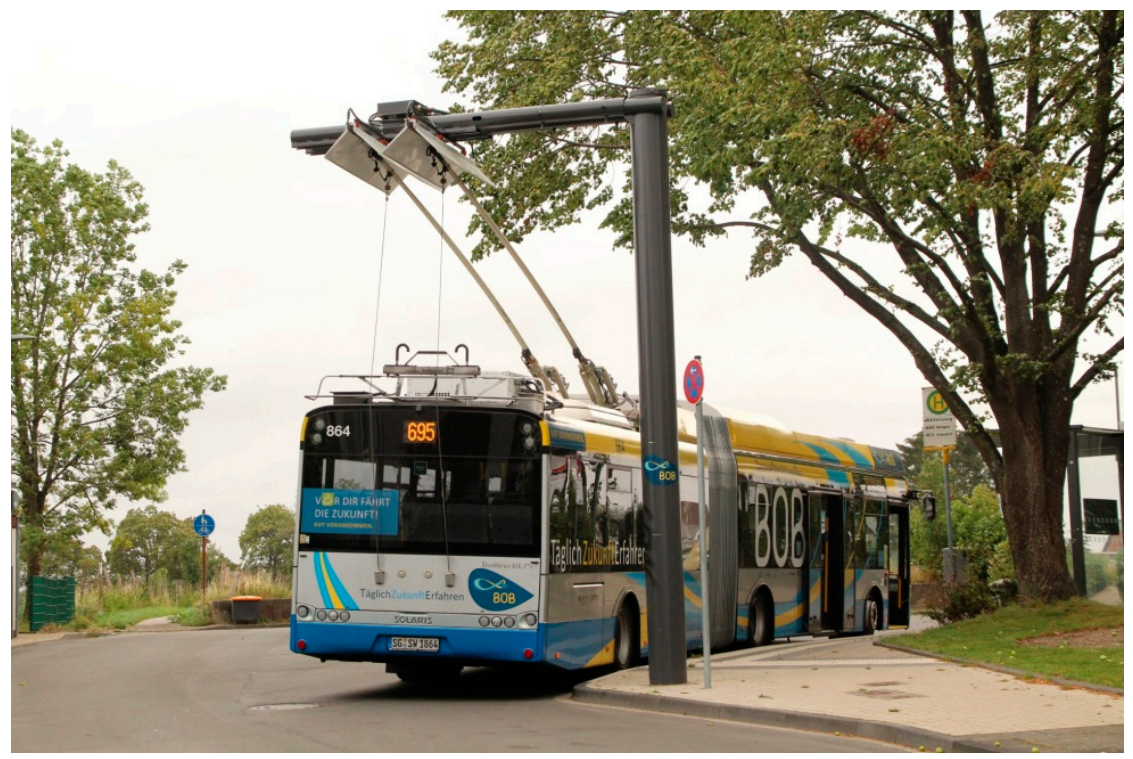

Figure 1. Trolleybus charging station in Solingen (photo taken by M. Bartłomiejczyk). 


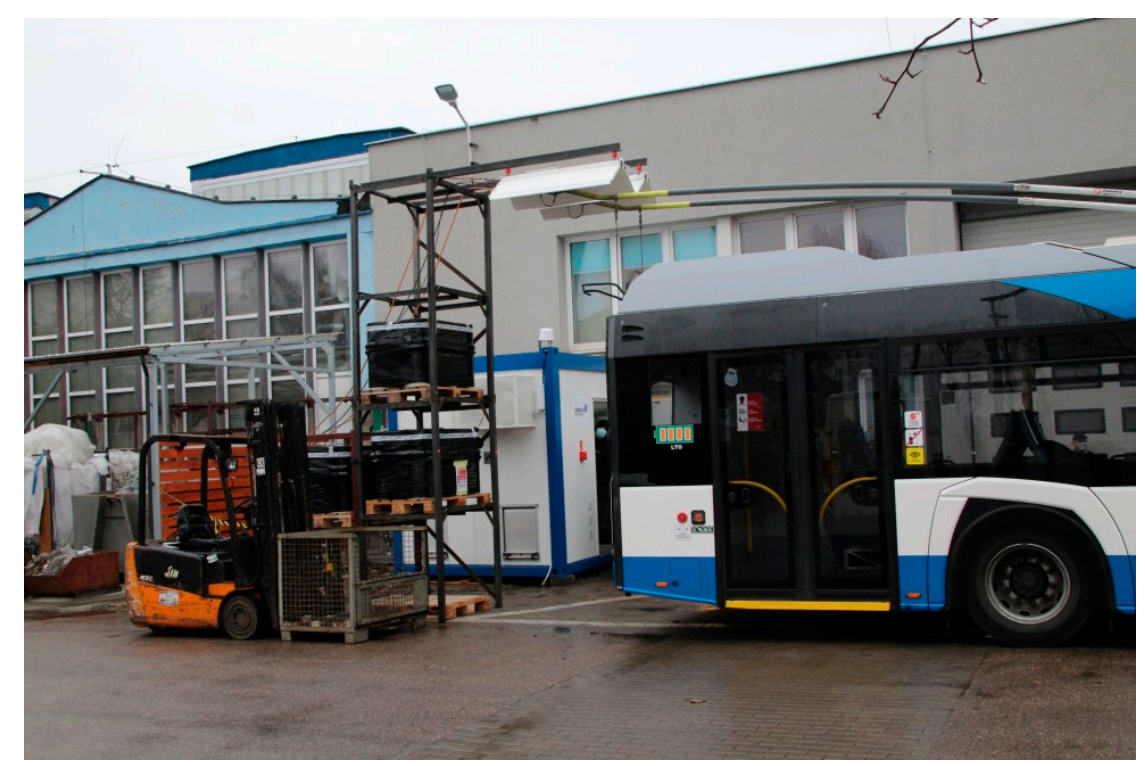

Figure 2. Technical tests of a prototype of a $150 \mathrm{~kW}$ fast charging station for trolleybuses in Gdynia (photo taken by M. Bartłomiejczyk).

The difference between electric buses and trolleybuses mainly concerns two aspects: the overhead contact network (power supply) and the size of on-board batteries. Although, despite the latest research [15], a problem of social reception may arise in the case of OHL, it gives an opportunity to recharge on-board batteries while in motion [34]. This contributes to a reduction in their size, and thus to a smaller limitation in the number of passenger seats. This is a key issue for the organisation of public transport. An electric bus, which can only be recharged when stationary in a depot or at a terminus, must have a high-capacity battery, which translates into its own weight and limits the number of passenger seats in the vehicle. Limiting the supply of seats requires increasing the number of connections, and this affects the economic balance of the entire investment.

The development of trolleybus transport using partially autonomous vehicles is a very attractive solution for cities that already have the OHL infrastructure. To illustrate the legitimacy and effectiveness of such a solution, the example implemented in Gdynia in 2020 was used (Figure 3).

Within the existing network of transport connections, a decision was made to electrify bus line 170, whose route ran from the centre of Gdynia to the Pogórze Dolne district, partly under the trolleybus overhead wiring network. Pogórze Dolne is an area of the city with no access to the trolleybus system, and it is served only by diesel buses. In order to expand zero-emission connections spatially, it was decided to convert line 170 into a trolleybus line number 32 served by trolleybuses with the In-Motion-Charging technology. The route of the line was slightly extended in the city centre so that $40 \%$ of its length was covered with OHL. Additionally, a short branch of the OHL was built so that trolleybuses could conveniently disconnect and connect to the overhead line. The use of an automated process of connecting and disconnecting trolleybuses from/to OHL makes the process avoid collision with the traffic of public transport vehicles. Disconnection from OHL takes place at the stop during the scheduled stop and lasts exactly as long as the replacement of passengers and the assumed normal stop time. In order to connect to OHL, special cable covers are mounted, which guide the pantograph rods to them. The pantograph rods are controlled automatically without the driver's participation. The process takes place at a similar time to disconnection from OHL. The cost of creating additional infrastructure amounted to PLN 722,488.33 (approx. EUR 160,000). To operate the new route, six Solaris Trollino $12 \mathrm{M}$ trolleybuses were purchased, which were equipped with $87 \mathrm{kWh}$ on-board batteries constructed in the LTO technology. The unit cost of such a trolleybus was PLN 2,257,000 net (approx. EUR 500,000). Trolleybuses have double 
certification of approval: both as an electric bus and a trolleybus. While driving under the overhead line, the vehicle charges on-board batteries whose capacity is sufficient to serve the section devoid of the OHL. An effective use of the existing power supply infrastructure and a small complementary investment exemplify a possibility of easy spatial development of trolleybus connections.

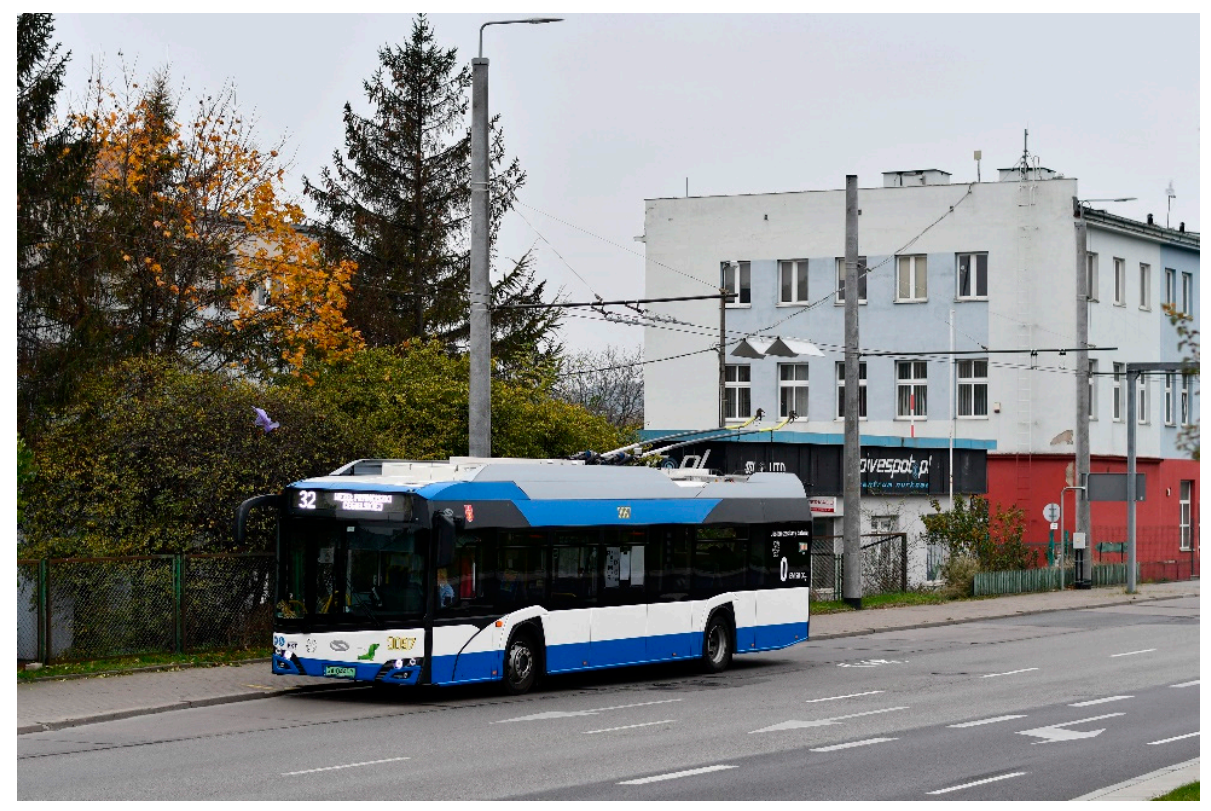

Figure 3. The process of automatic connection to the overhead line of a Solaris Trollino $12 \mathrm{M}$ trolleybus on line 32 (photo taken by K. Grzonka).

\subsection{Research Goals}

An analysis of the available scientific literature showed a research gap in the field of spatial development of trolleybus connections using the In-Motion-Charging technology. The relative ease of implementation of electric buses may lead to later operational and financial difficulties connected with a need to replace large on-board batteries. Using the existing trolleybus overhead contact system and operating connections on sections without it by trolleybuses with small batteries is an alternative solution.

The article attempts to answer the following research questions:

1. are partially autonomous trolleybuses an alternative to electric buses?

2. is it possible to develop connections effectively by electrifying bus lines having the trolleybus overhead line infrastructure at one's disposal?

3. what is the optimal level of coverage of a bus line with OHL to meet the conditions for its operation with partially autonomous trolleybuses?

4. what is the impact of congestion on the designed size of traction batteries in trolleybuses?

5. what is the minimum power of the charger to charge a battery in a trolleybus?

\section{Materials and Methods}

The analysis of the possible electrification of the current bus lines based on dynamically charged trolleybuses will be based on the calculation of the required battery charging power. Assuming the battery is fully charged in each driving cycle, the energy $E_{\text {aut }}$ consumed from the battery while driving with autonomous power supply must be equal to the power delivered during charging $E_{c h}$ :

$$
E_{a u t}=E_{c h}
$$


The battery can be charged in motion from OHL (dynamic charging) and outside the contact system from a stationary charger:

$$
E_{\text {aut }}=E_{c h \_I M C}+E_{c h \_s t}
$$

where:

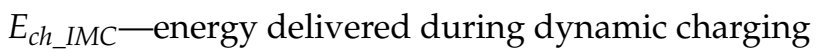

$E_{\text {ch_st }}$ - energy delivered during stationary charging.

This dependence can be expressed as:

$$
l_{\text {aut }} \times k\left(P_{I M C}\right) \times t_{O H L} \times P_{I M C}+t_{s t} \times P_{I M C}
$$

$l_{\text {aut }}$-driving range on battery power

$t_{\mathrm{OHL}}$-driving time with power supply from the overhead line

$t_{s t}$-stationary charging time

$e$-energy consumption

$P_{I M C}$ - charging power

$k\left(P_{I M C}\right)$ - coefficient of exploitation of the maximum IMC charging power (Figure 4)

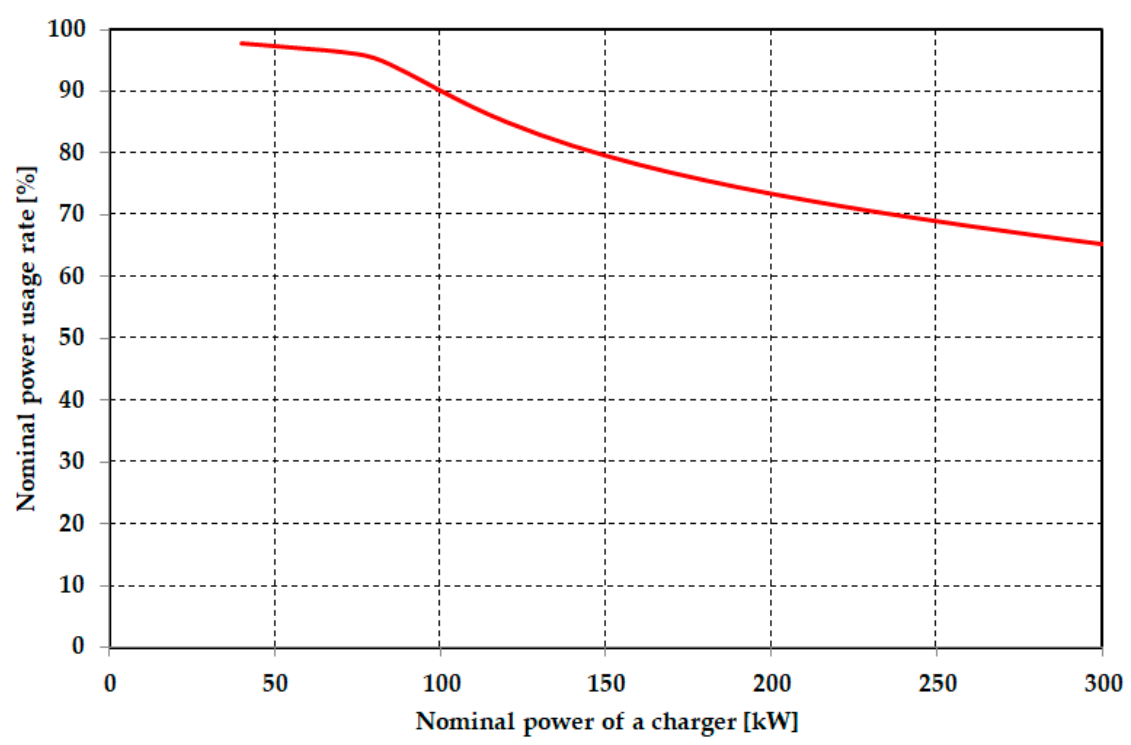

Figure 4. Nominal usage of the charger power (source: own elaboration).

This becomes:

$$
P_{I M C}=\frac{l_{\text {aut }} \times e}{k\left(P_{I M C}\right) \times t_{O H L}+t_{s t}}
$$

Calculating the $P_{I M C}$ power requires solving Equation (3). If the calculated charging power exceeds the allowed maximum output power $P_{\text {st_max }}$ of a fast charging station, then power $P_{I M C}$ is expressed as:

$$
P_{I M C}=\frac{l_{a u t} \times e-t_{s t} \times P_{I M C}}{k\left(P_{I M C}\right) \times t_{O H L}}
$$

In the adopted model, charging the vehicle battery takes place partly in motion in the IMC system and partly in a stationary way at the terminus. In the event of a delayed arrival, the parking time is reduced, and hence the charging time is reduced. However, in the case of dynamic charging, the impact of congestion on the charging time is of a different nature. The travel time on the section of the route with an overhead contact line, i.e., the charging time, does not fall below the minimum value resulting from the traffic speed. Moreover, the difficulties resulting from the traffic congestion extend the travel time 
and thus may improve the charging conditions. Therefore, sensitivity coefficient $c$ can be defined, which allows a qualitative assessment of the sensitivity of the charging system of a communication line to congestion:

$$
c=\frac{P_{I M C \_0}-t_{s t} \times P_{I M C \_6 m i n}}{P_{I M C \_0}}
$$

where:

$P_{\text {IMC_6min }}$ IMC charging power, assuming a 6-min stop at the terminus $P_{\text {IMC_0 }}$-IMC charging power assuming no stop at the terminus

The value of the sensitivity coefficient provides information on how many times the dynamic charging power should be increased in order to fully charge the battery with no stationary charging. The smaller the value of coefficient $c$, the greater the share of dynamic charging in the total vehicle charging cycle, and thus the independence of the charging process from the traffic conditions. On the other hand, the significant value of coefficient $c$ means a need to increase the battery capacity in order to maintain a reserve in the event when it is not possible to fully charge it.

The charging power is a key element affecting the operation of electric vehicles. In the case of IMC charging systems, the main limitation of the charging power is the maximum permissible current carrying capacity of trolley poles. In the currently used solutions, it is 500-600 A, which allows for charging with the power of 300-500 kW. However, due to thermal restrictions, the permissible current consumed from the network during a stop drops to approx. $150 \mathrm{~A}$, which limits the degree of using the maximum power, i.e., the average useful charging power. Figure 4 shows the relationship between the maximum charging power and the degree of its use. The diagram was prepared on the basis of recording the current consumed by an articulated trolleybus in winter conditions. The increase in the maximum charging power is associated with the complexity of the structure and an increase in the price and weight of the charging converter. For this reason, it should be used as much as possible. The highest usage rate, close to one, is at the nominal converter power at the level of $80-90 \mathrm{~kW}$, but this power is insufficient in many cases. Moreover, the present level of development of power electronic devices allows for the construction of converters with higher power. With a power of $150 \mathrm{~kW}$, it is possible to use the charger in $80 \%$, which can be considered the optimal power level. Due to the decrease in the usage rate, a further increase in power is unjustified.

\section{Study Area-The Case Study of Gdynia in Poland}

In Polish conditions, Gdynia is a large city with almost 250,000 residents. It is located in the northern part of Poland on the coast of Gdańsk Bay. The spatial development of the city began in the 1920s. Due to the difficult access to the seaport in Gdańsk, Polish authorities started building their own access to the sea through a port located in Gdynia. Thus, Gdynia began to develop dynamically from a small fishing village to a large industrial centre. Due to the moraine terrain and the resulting large difference in elevation, the construction of trolleybus connections started already during the war occupation in the 1940s [88]. The system in Gdynia was so large that, despite departure from electric public transport in the 1960 s on the wave of global trends, the connections in Gdynia were not fully closed. In the following years, due to the fuel crisis that affected the global economy, the development of electric urban transport was resumed, and thus also in Gdynia the development of trolleybus connections started again. Another regression occurred with the economic crisis of the 1980s and the political and economic transformations after 1989. The underinvested infrastructure and rolling stock created increasingly greater operational difficulties. As in the 1960s, in the 1990s the maintenance of trolleybus transport resulted from the scale of its operation. In the same period, three other trolleybus networks were closed in Poland (in Dębica, Słupsk and Warsaw) [78]. The situation significantly changed after Poland's accession to the European Union in 2004. Thanks to the aid funds, modernisation and 
development of the existing public transport systems started, including the trolleybus system in Gdynia [58,63,89].

\subsection{Operating Conditions}

Trolleybus transport in Gdynia was launched in September 1943 to ensure smooth transportation for the population considering simultaneous problems with the supply of liquid fuels during the war [90]. After the end of warfare, trolleybus connections were resumed in 1946. The volume of transport and the spatial range of trolleybus connections varied. Due to the regression of electric public transport in the 1960s and 1970s, only two lines operated in Gdynia at the turn of the 1970s and 1980s. In the following years, due to the global fuel crisis, Gdynia returned to trolleybus transport and a new spatial development of connections. In consequence, new routes were built [78,90]. The 1990s brought a regression caused by political and economic changes in Poland. The departure from the centrally controlled economy and the transfer of responsibility for urban transport to local governments affected the level of financing, decapitalisation of infrastructure, and rolling stock. As mentioned before, only Poland's accession to the European Union in 2004 contributed to the modernisation and development of urban transport, including trolleybus [90]. Since then, the Gdynia trolleybus system, which also serves the neighbouring city of Sopot, has been developing dynamically. Many technological and organisational innovations have been introduced. The trolleybus operator joined many international projects, becoming a leader of change [91-93]. The particular achievements of the Gdynia trolleybus system include the conversion of second-hand low-floor diesel buses into trolleybuses with the use of drives from scrapped vehicles [49], putting the first low-floor Solaris trolleybus into operation in 2001, which now is the most popular trolleybus brand in Europe [51,52], and launching the use of trolleybuses with on-board batteries in 2009. At that time, the battery technology was not yet widespread, and only a few cities in Europe had any experience in this field [32]. Then the spatial development of trolleybus connections using on-board batteries started. In March 2021, there were eight lines, including two bus lines electrified by trolleybuses [94]. Nowadays, trolleybus transport in Gdynia serves over 30\% of passengers and covers over 5 million vehicle kilometres per year [78].

The trolleybus network in Gdynia covers most of the city (Figure 5). These are residential areas and partly industrial and service ones. They are characterised by a high population density. Trolleybus lines run along the main traffic routes. Figure 6 shows the trolleybus transport network in the context of population density, which indicates disproportions in the spatial availability of zero-emission transport. The northern and western parts of the city, which are densely populated, do not have such connections. On the map, they are marked as the following districts: Pogórze, Obłuże-Oksywie, ChwarznoWiczlino, Witomino, and Płyta Redłowska.

It should be noted that many of the sections of routes with high frequency of buses overlap with sections of the trolleybus OHL network. This network can be used to charge electric buses on the move, i.e., for the electrification of bus lines.

Figure 7 shows the percentage of the bus routes in Gdynia running under the trolleybus wiring. In many cases, it is at least $20 \%$, so it marks them out to be operated by trolleybuses in the IMC system. Moreover, the construction of additional sections of OHL may adapt the existing overhead wiring network to dynamic charging. In analysis of the intensity of operation of bus lines (Figure 8) and the present trolleybus network (Figure 6), three sections can be marked out for the construction of an overhead contact line (Figure 9). These sections are characterised by a high frequency of bus connections. Furthermore, they are relatively short, and their layout corresponds to the existing structure of the trolleybus network. Based on this, the variants adopted for analysis were determined (Table 2). 


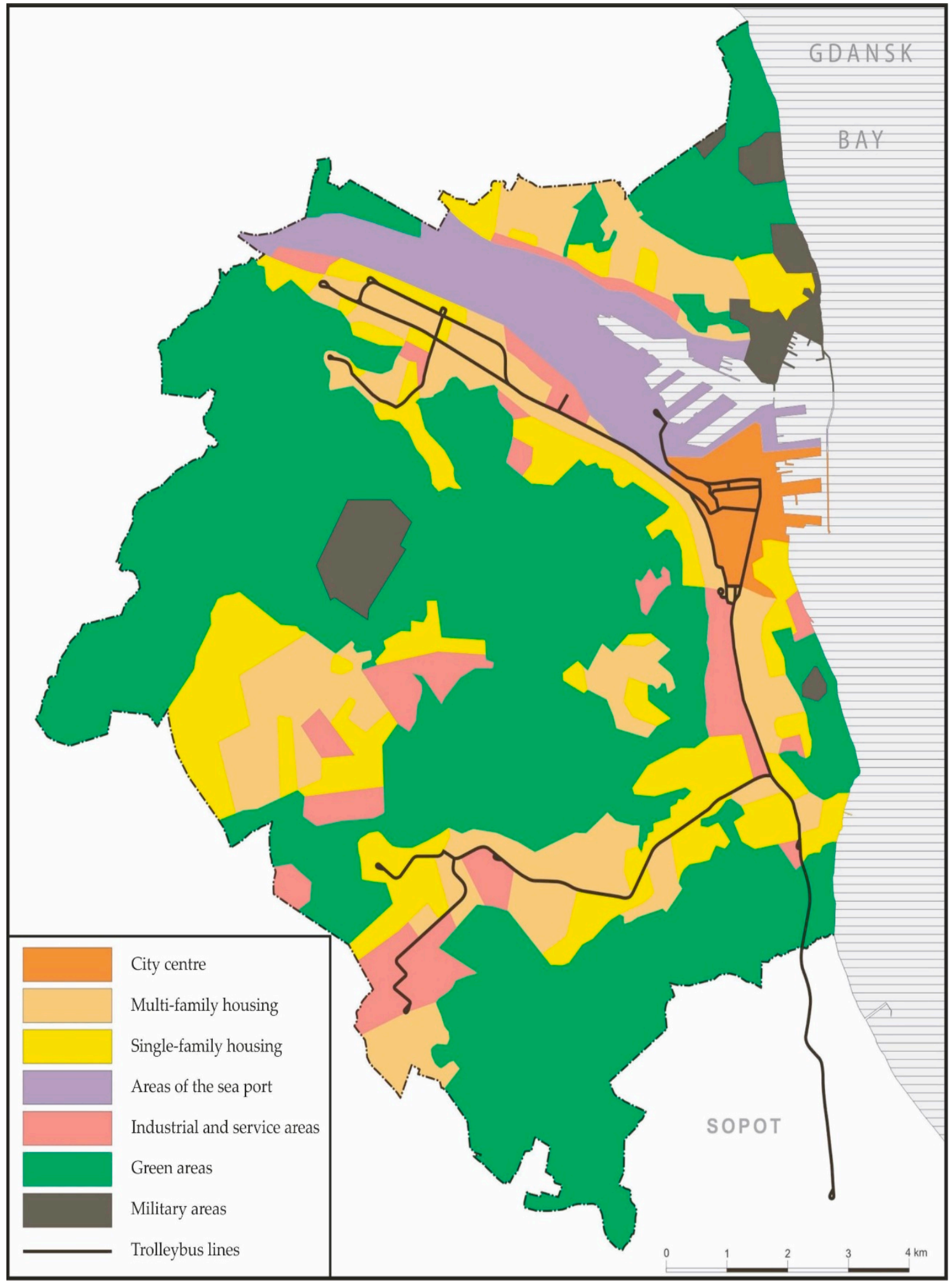

Figure 5. Trolleybus transport network in Gdynia in the context of the functional and spatial structure of the city (source: own elaboration). 


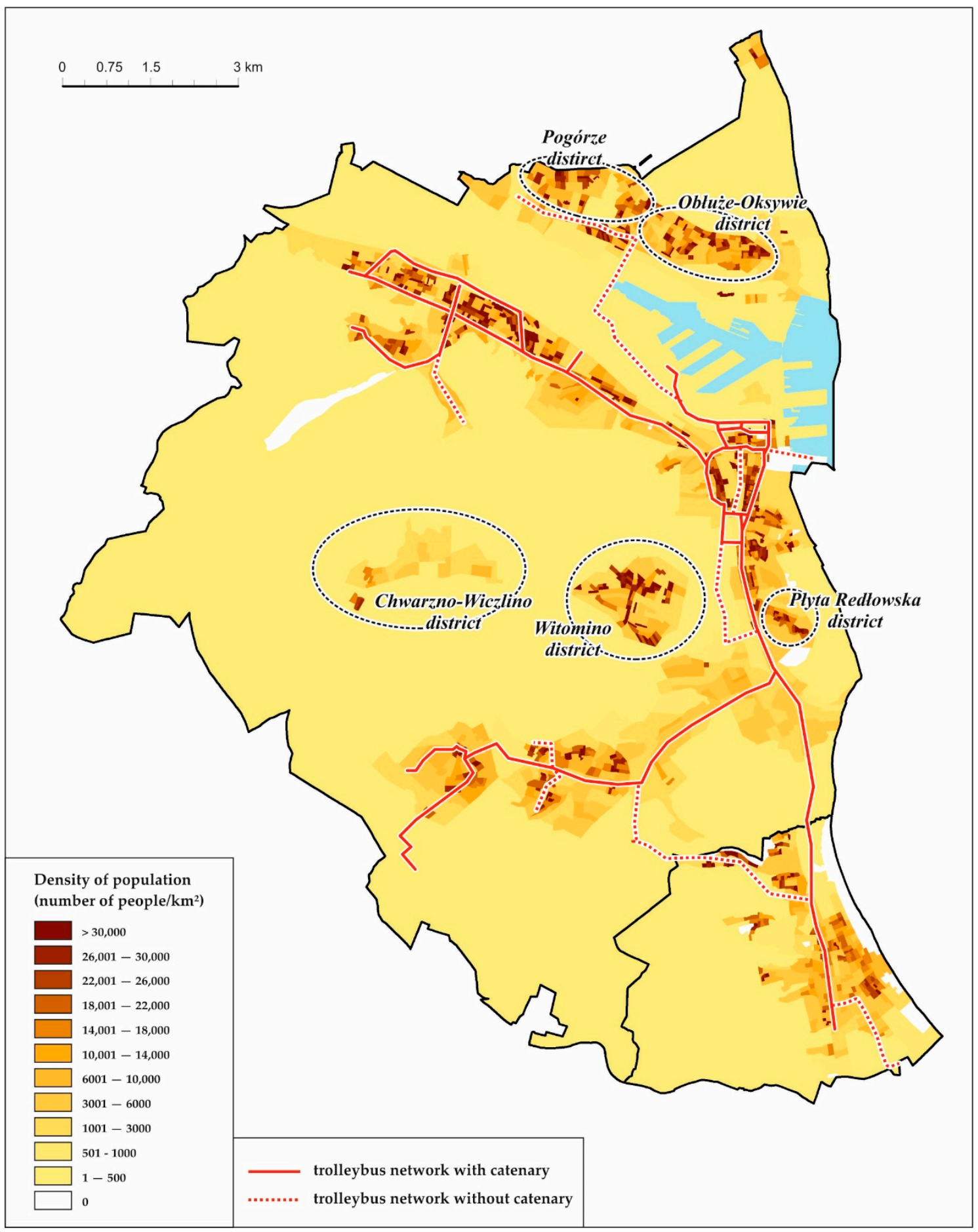

Figure 6. The public transport network in Gdynia in the context of the population density (source: own elaboration). 


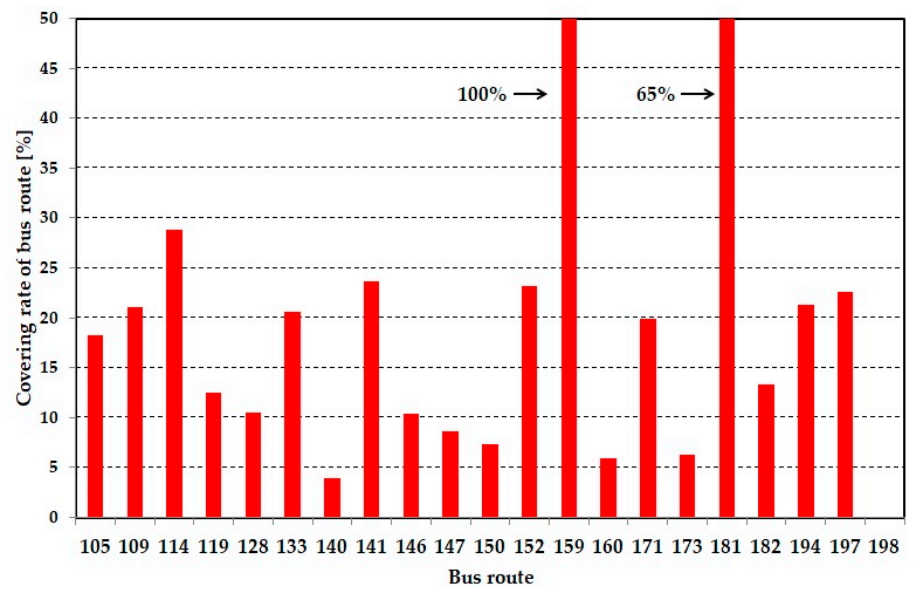

Figure 7. Coverage of bus lines with a trolleybus overhead contact system (source: own elaboration).

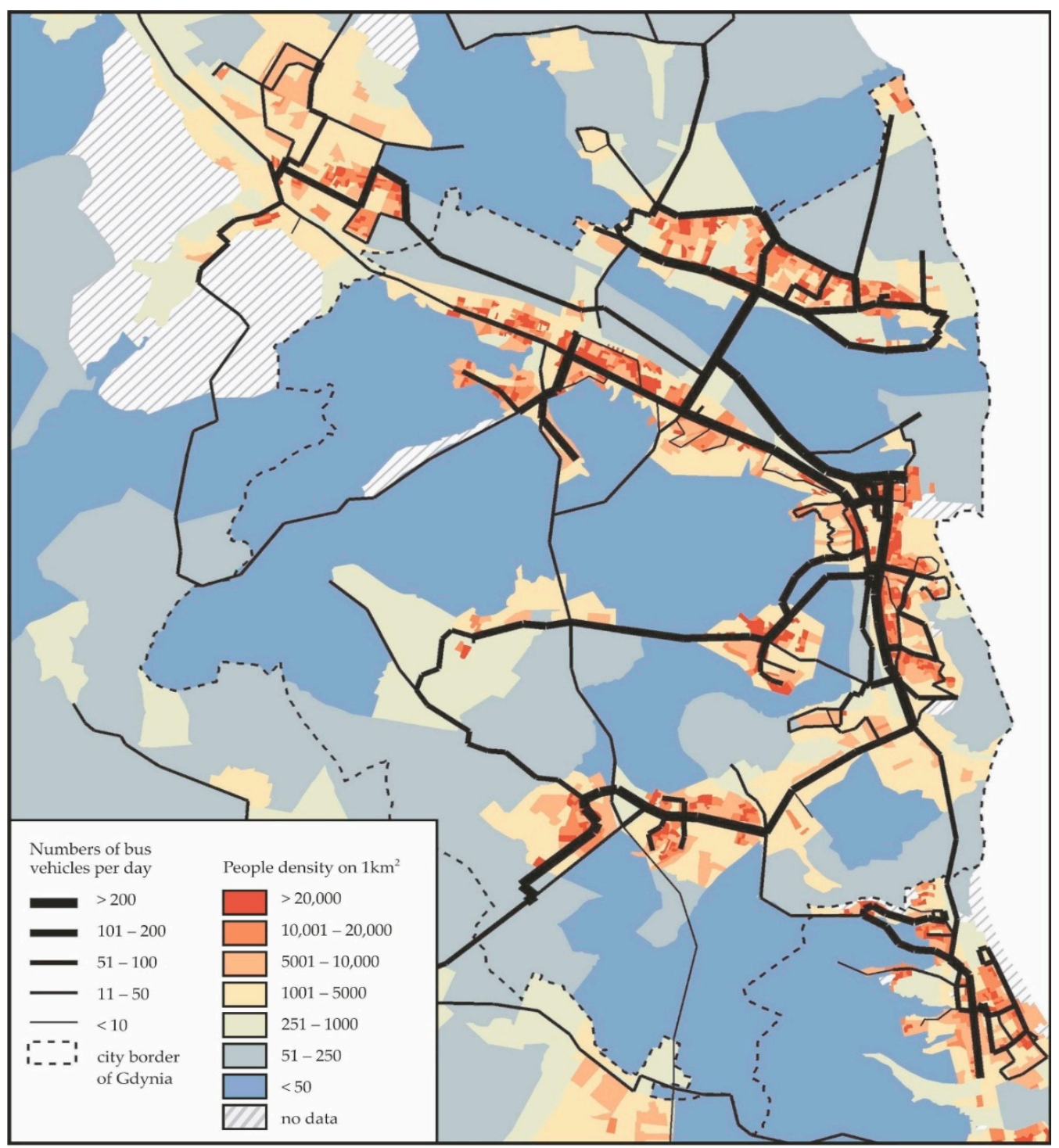

Figure 8. The traffic intensity of bus lines compared to the population density (source: own elaboration). 


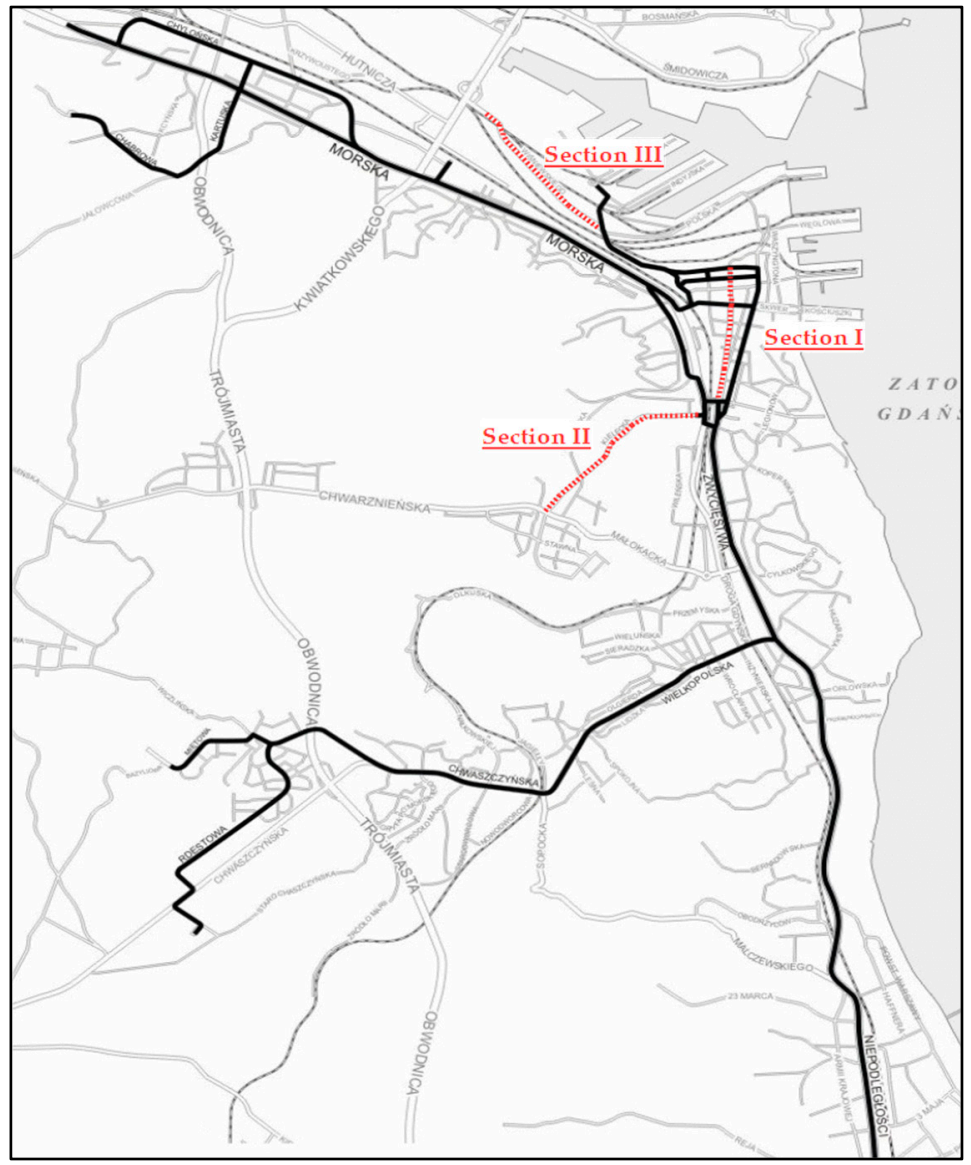

Figure 9. The possibilities (red lines) of extending the existing (black line) trolleybus network in Gdynia (source: own elaboration).

Table 2. Comparison of the proposed section of overhead lines (OHL) (source: own elaboration).

\begin{tabular}{cccc}
\hline Section & Route Description & Length & Additional Investment Required \\
\hline Section I & Władysława IV & $2 \mathrm{~km}$ & - \\
\hline Sections II & $\begin{array}{c}\text { Kielecka (Wzgórze-Witomino } \\
\text { Centrum) }\end{array}$ & $1.8 \mathrm{~km}$ & Placing power cables \\
\hline Sections III & $\begin{array}{c}\text { Janka Wiśniewskiego to } \\
\text { Energetyków }\end{array}$ & $1.9 \mathrm{~km}$ & $\begin{array}{c}\text { Placing power cables and } \\
\text { constructing a new substation }\end{array}$ \\
\hline
\end{tabular}

\subsection{Experience in Using Autonomous Trolleybuses in Gdynia}

Experience in the development of trolleybus connections in Gdynia began in 2009, when two trolleybuses with on-board nickel-cadmium batteries with a capacity of $16 \mathrm{kWh}$ were put into operation, which allowed for trips of 3-7 km [78]. Good experiences in this respect resulted in the widespread use of batteries in the Gdynia rolling stock. Subsequent trolleybuses were equipped with the same batteries. Even vehicles converted from diesel buses received small $8 \mathrm{kWh}$ on-board batteries for a possible emergency short trip. At that time, tests started to use batteries on a short off-the-network section of line 21 in the city centre. Along with the development of battery technologies, new trolleybuses were equipped with lithium-ion batteries with a capacity of $40 \mathrm{kWh}$ and then $69 \mathrm{kWh}$, which allowed for a trip of up to $15 \mathrm{~km}$ and then $30 \mathrm{~km}$ and the route use. Thanks to these trolleybuses, in 2016, line 29 was launched to the Fikakowo district, in which the last section does not have an OHL. The low frequency of trolleybuses (every 15-30 min) would be uneconomical to build an overhead contact network, and the dense housing development would make it difficult to carry out the investment. Very good experience in 
the functioning of the first route operated by partially autonomous trolleybuses resulted in the purchase of more trolleybuses. These were standard vehicles with a capacity of $58 \mathrm{kWh}$ and articulated vehicles with a capacity of $87 \mathrm{kWh}$. Thanks to them, new connections were launched on sections without an OHL network (lines 27, 31, 33, 34, 181, 320). The decision was also taken that in trolleybuses equipped with nickel-cadmium batteries, which after about 10 years of operation needed replacement, they should be replaced with lithiumpolymer batteries with a capacity of $40 \mathrm{kWh}$, which significantly increased the operator's ability to handle connections on OHL-free sections. The last purchase concerned standard trolleybuses with a very large capacity of $87 \mathrm{kWh}$ which are used in the IMC technology to operate the electrified bus on line 170 (currently 32).

\section{Research Analysis}

The calculations of the possibility of operating individual bus lines by trolleybuses were made with the assumption of energy consumption corresponding to the consumption during difficult winter conditions, with the air temperature of -5 to -10 degrees Celsius. For standard length trolleybuses, it is $1.7 \mathrm{kWh} / \mathrm{km}$, and for articulated trolleybuses, it is $2.7 \mathrm{kWh} / \mathrm{km}$. The results of calculations of the required charging power for particular routes are shown in Figure 10. The assumed charging time at the terminus is 6 min. Figure 11 presents the value of the sensitivity coefficient $c$.

Figure 12 shows the effect of IMC charging power on the possibility of increasing the transportation work of electric vehicles. The maximum driving range on battery power with no stationary charging at the terminus, which may take place in the case of a long delay in traffic, is also an important parameter (Figure 13). This value determines the required capacity of the traction battery.

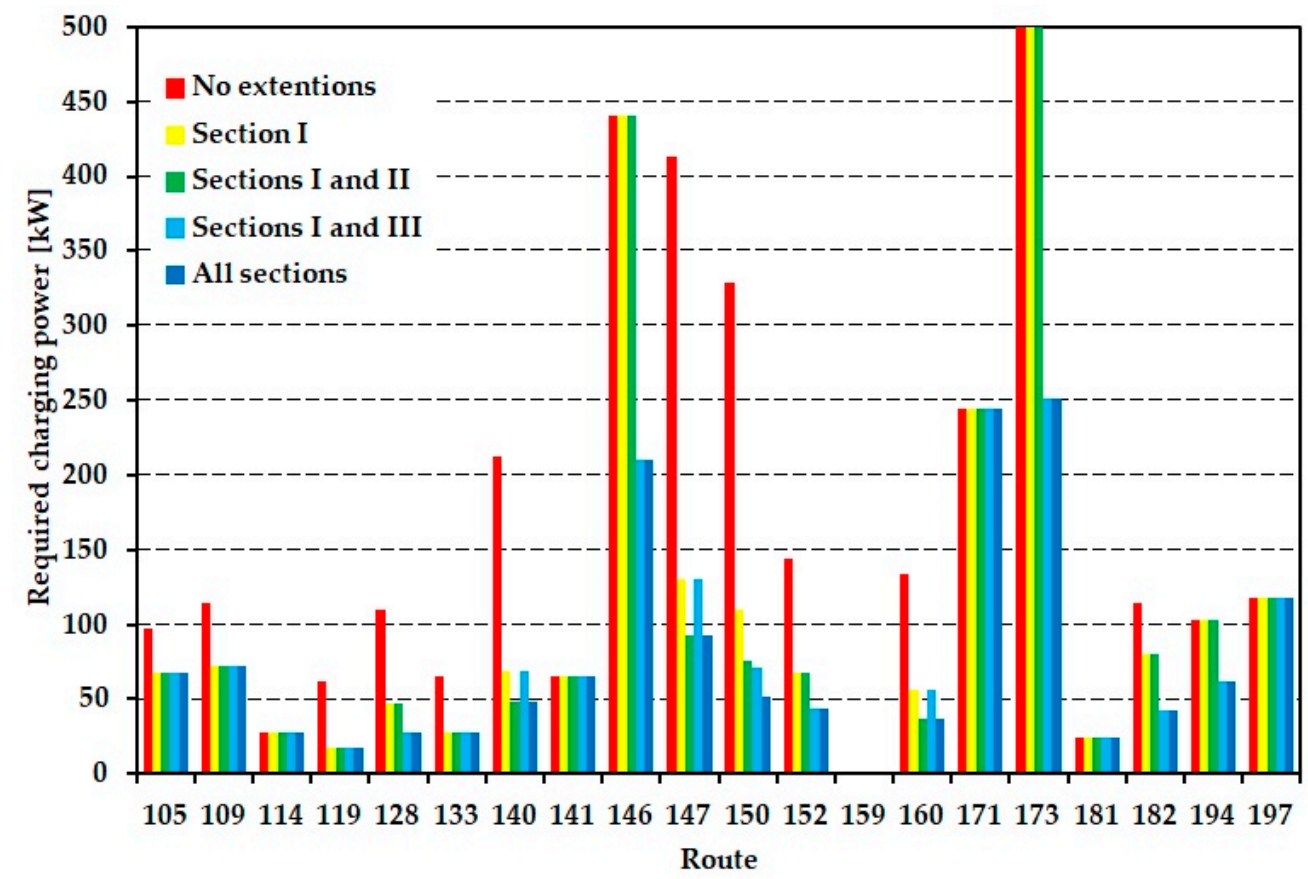

Figure 10. Values of the charging power which allow operating bus routes by IMC electric buses for several variants of trolleybus network extension with additional charging at the terminuses (source: own elaboration). 


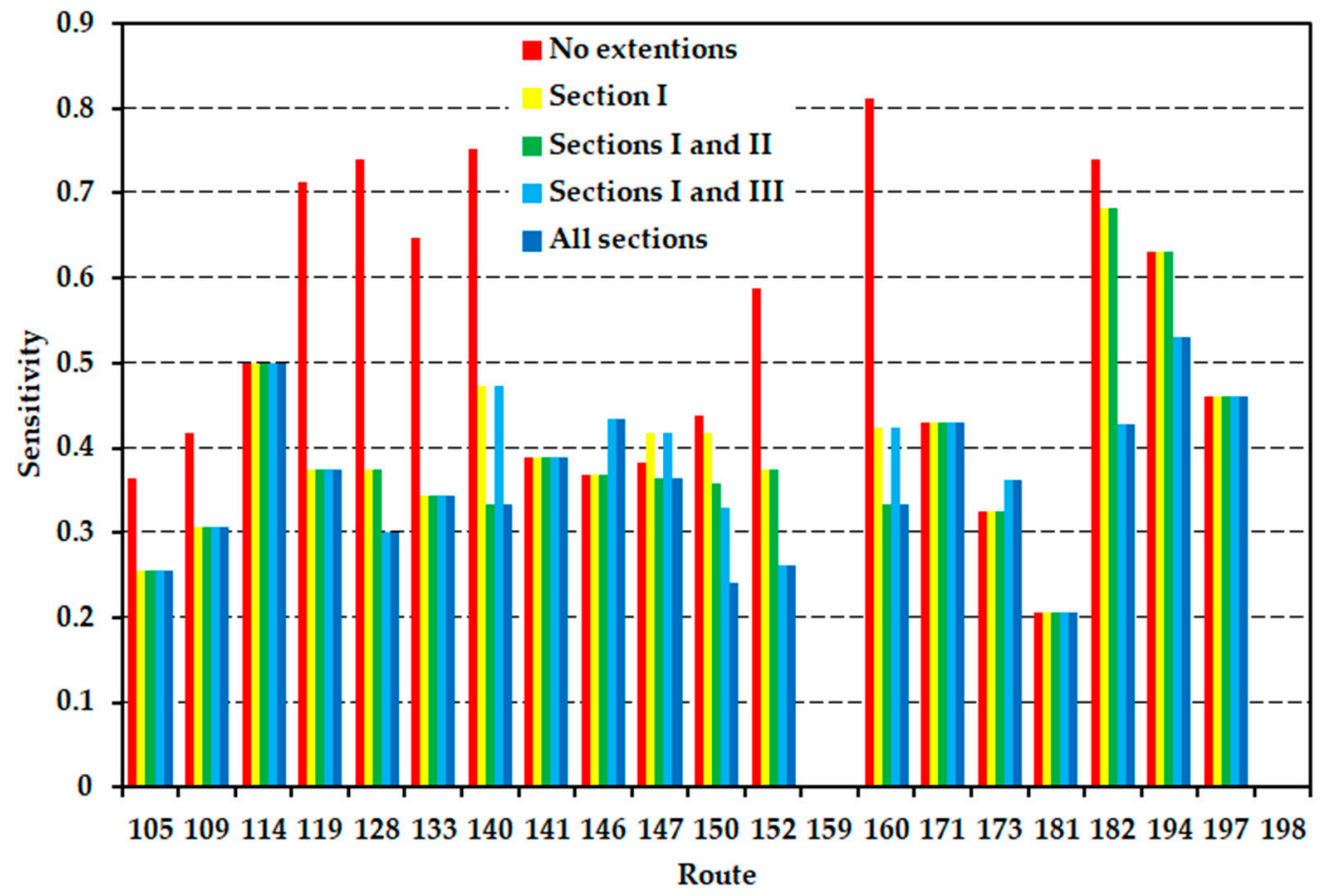

Figure 11. The value of the sensitivity coefficient (source: own elaboration).

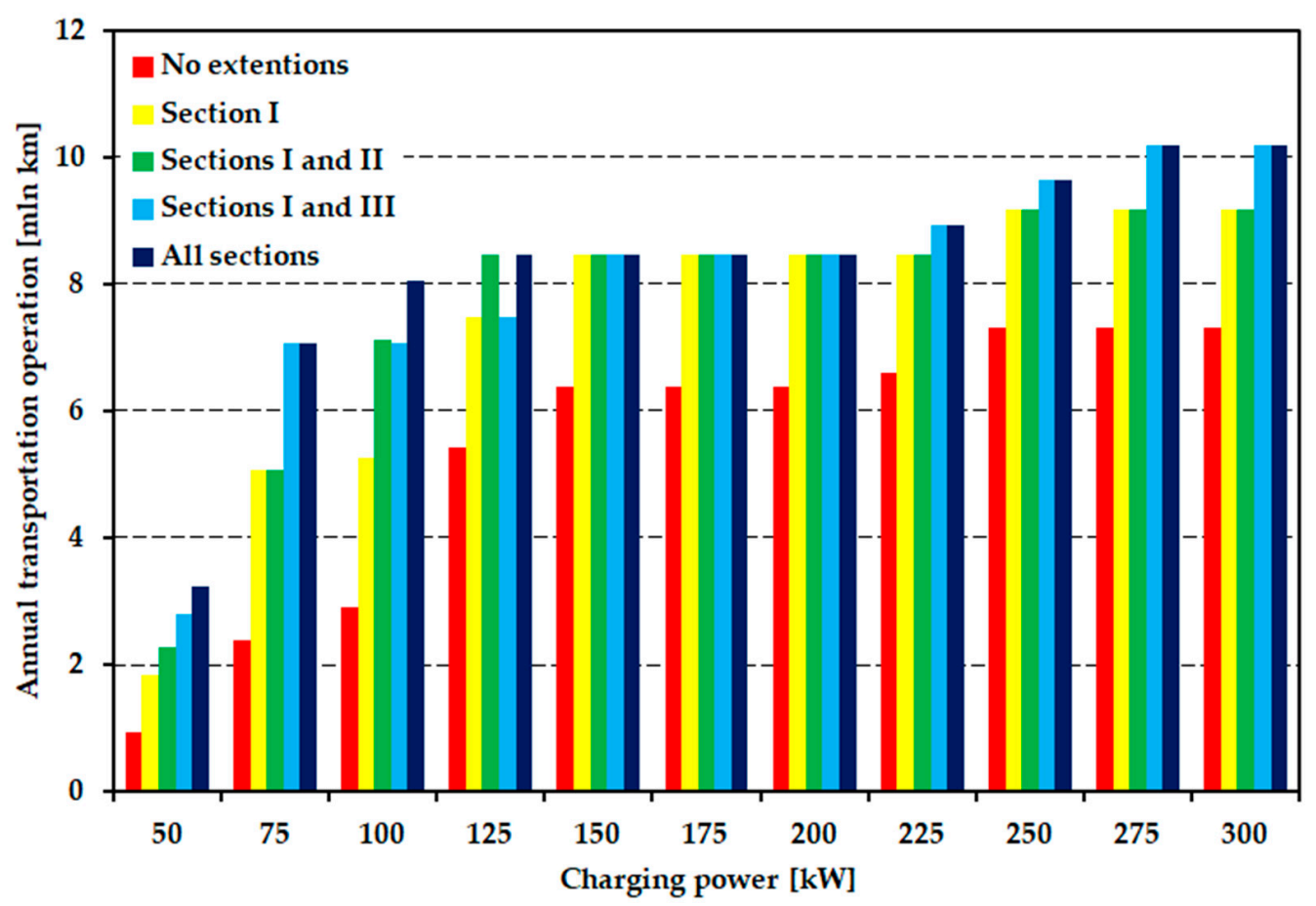

Figure 12. Potential of increasing the transportation work by implementation of dynamic charging based on the existing trolleybus infrastructure in Gdynia in the function of charging power for several variants of trolleybus network extension (source: own elaboration). 


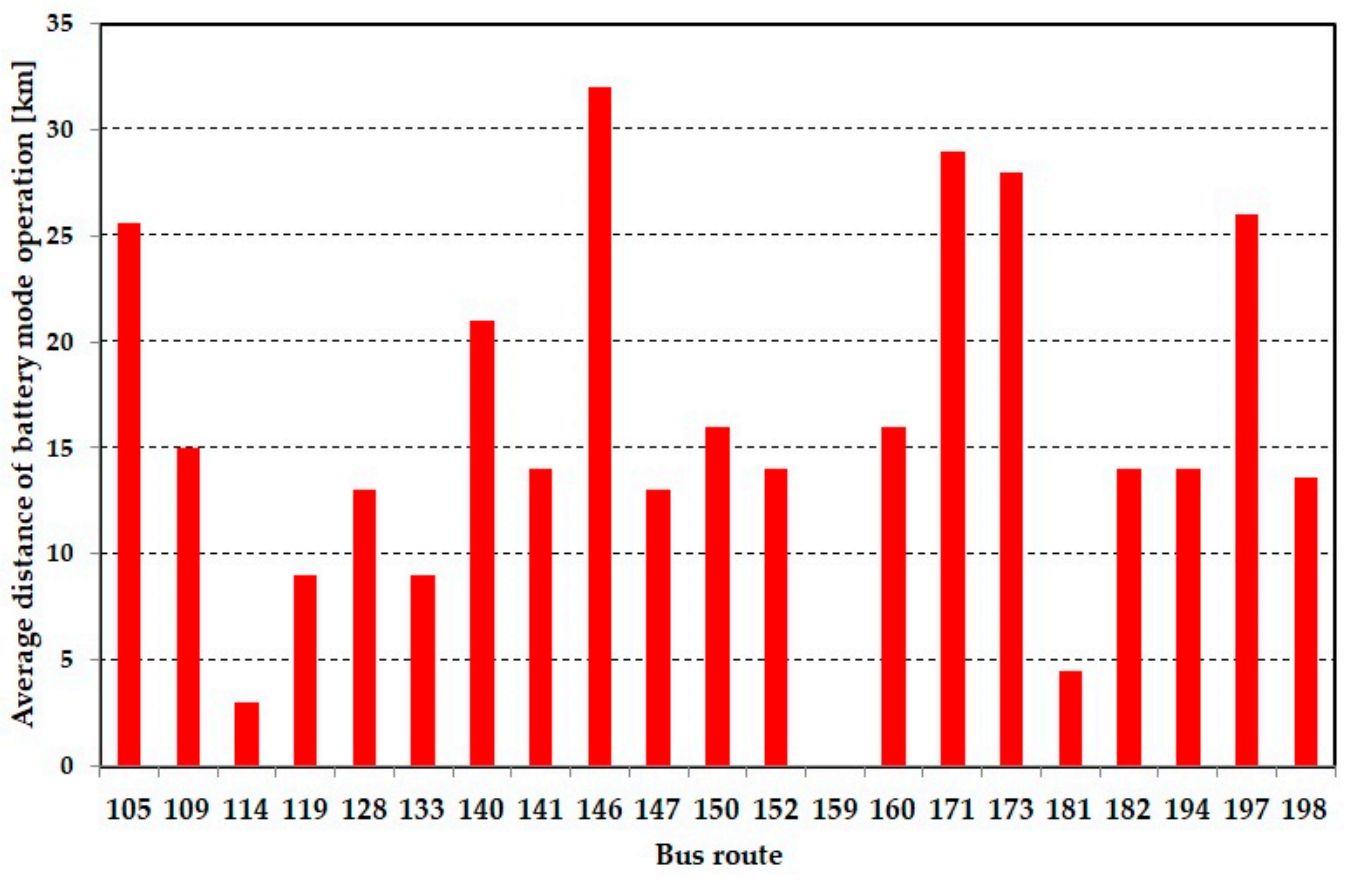

Figure 13. Maximum driving range on battery operation (source: own elaboration).

\section{Interpretation of Research Results}

There are three criteria for evaluating the possibility of electrification of a public transport route with the In-Motion Charging system (IMC):

1. the minimum power of the vehicle charger, which determines whether the vehicle will be able to charge the traction battery;

2. the maximum driving range on battery power, which determines the minimum capacity of the traction battery;

3. sensitivity coefficient $c$, which determines the extent to which the battery will be charged in the dynamic mode and the stationary mode. This coefficient carries information about the sensitivity of the charging process to congestion; greater sensitivity means a need to increase the capacity of the traction battery in the event of traffic disruptions.

In Gdynia, bus routes 115, 159, and 181 should first be assigned to operation with trolleybuses (route 181 has been partially operated with trolleybuses since 2019). Then, it is possible to select lines for electrification that run under the existing overhead contact system at $20-25 \%$ of their length. After building supplementary fast charging stations at terminuses, they can be replaced with battery trolleybuses. These are mainly lines 109 and 141. In the case of line 109, it is possible to consider the modification of the final section of its route in Wzgórze Świętego Maksymiliana to make better use of the existing overhead contact network in this area (the terminus at Franciszki Cegielskiej interchange and the OHL in Zwyciestwa Alley). Line 194 is another route that meets the conditions for electrification. Although it is characterised by an unfavourable coefficient of sensitivity to congestion (Figure 9), due to the relatively short driving distance on battery power, it is possible to provide sufficient capacity reserve without a need to oversize the traction batteries. Subsequently, routes 105 and 197 can be earmarked for electrification, but their operation requires the use of a battery with a relatively large capacity or ensuring a guaranteed stop at the terminus for charging (Table 3). It should be mentioned that in emergencies (no bus fleet) route 105 is operated by trolleybuses, which indicates its potential to implement dynamic charging. The analysis also showed the possibility of electrification of routes 119,128 , and 133 . However, these routes only minimally overlap 
with the existing OHL, so their service would be mainly based on stationary charging (very high sensitivity coefficient $c$ ).

Table 3. Investment variants related to the development of trolleybus transport in Gdynia (source: own elaboration).

\begin{tabular}{|c|c|c|}
\hline Variant & Opportunities and Benefits & Public Transport Routes \\
\hline \multirow{4}{*}{ No extensions } & $\begin{array}{l}\text { Line service with trolleybuses without } \\
\text { investment }\end{array}$ & $114,159,181$ \\
\hline & $\begin{array}{l}\text { Line service with trolleybuses after the } \\
\text { construction of fast charging stations }\end{array}$ & $109,141,194$ \\
\hline & $\begin{array}{l}\text { Line service with trolleybuses after the } \\
\text { construction of fast charging stations and } \\
\text { increasing the battery capacity }{ }^{1}\end{array}$ & 105,197 \\
\hline & $\begin{array}{l}\text { Line service with trolleybuses in the } \\
\text { electric bus mode after the construction } \\
\text { of fast charging stations }\end{array}$ & $119,128,133$ \\
\hline \multirow{2}{*}{ Section I } & $\begin{array}{l}\text { Line service with trolleybuses after the } \\
\text { construction of fast charging stations }\end{array}$ & $140,147,150,152,160,182$ \\
\hline & Decreasing the battery capacity ${ }^{2}$ & $105,109,119,128,133$ \\
\hline Sections I and II & Decreasing the battery capacity ${ }^{3}$ & $140,147,150,160$ \\
\hline Sections I and III & Decreasing the battery capacity ${ }^{3}$ & $150,152,182,194$ \\
\hline
\end{tabular}

Further development of the network of routes operated by IMC trolleybuses is possible after the construction of an OHL in Władysława IV Street. A substantial number of bus routes run there, which will enable a use of the constructed infrastructure by many lines. This will allow the electrification of routes in the direction of so-called Gdynia West, i.e., $140,147,150,160$, as well as routes 152 and 182. Optimisation of the routes selected for electrification in the previous variant (battery capacity reduction), i.e., 105, 109, 119, 128, and 133, will also be possible. The multifunctional use of the constructed infrastructure is also an argument in favour of building a trolleybus network in Władysława IV Street, because in addition to the electrification of bus lines, modification of the existing trolleybus routes will also be possible (transfer of some traffic from Świętojańska Street). A possibility of using the already existing elements of the trolleybus network power supply system, i.e., Kielecka substation and the power cable at Świętojańska Street, is an important factor as well.

The construction of sections of the overhead contact network in Kielecka Str. (Section II) and Janka Wiśniewskiego Str. (Section III) may be the next stage in the development of the trolleybus network. The main benefit will be the possibility to reduce the capacity of traction batteries in vehicles.

In addition to the evaluation of individual bus routes from the point of view of their electrification, the charging power in the dynamic system has also been optimised. Based on the analysis of the extent to which the increase in charging power allows expanding the service of bus lines by trolleybuses (Figure 10), it can be concluded that $150 \mathrm{~kW}$ power is sufficient and even only $100 \mathrm{~kW}$ in the case of expansion of the overhead contact network.

\section{Conclusions}

The presented model is based on the following stages of calculations:

- preliminary determination of routes predestined for the construction of OHL on the basis of the bus line traffic density map (Figures 8 and 9); 
- determination of the minimum charging power in IMC system for various variants of the OHL (Figure 10, Equations (1)-(5));

- determination of the sensitivity coefficient for individual variants (Figure 11, Equation (6));

- $\quad$ assessment of the possibility of electrification using various conditions based on the results of the calculations (Figure 12).

This model can be applied to any city, both with and without a trolleybus system.

The article presents the possibilities of using trolleybuses equipped with onboard batteries, charged in motion (IMC) to increase the share of zero-emission transport $[1,2,16,25-29,34]$. The development of battery technologies, in particular the lithium ones, which are characterised by a long service life and high capacity, allows for a new look at trolleybus transport [30,31,33,35,55-57]. Its position so far has been relatively weak. Only about 300 trolleybus systems all over the world made this means of transport rather unpopular $[15,78]$. The greatest weakness of trolleybuses-binding it to OHL, today may become their greatest advantage. Thanks to the power infrastructure, it is possible to charge on-board batteries on the move, which reduces the need for stops and the size of the installed batteries, as is the case with electric buses. The combination of the advantages of OHL and the relatively small size of on-board batteries increases the economic efficiency of trolleybus transport. Thanks to the use of partially autonomous trolleybuses, it has become possible to popularise zero-emission transport in areas with a lower population density, peripheral location, or without adequate financial resources to build an overhead contact network [78].

It has been shown that the optimal use of OHL permits a significant increase in the share of trolleybus transport in the public transport system. With an effective use of even a small trolleybus network by partially autonomous trolleybuses, cities can significantly increase the share of zero-emission transport at the place of operation.

In response to the research questions formulated at the beginning of the procedure, the resulting hypotheses were verified as follows:

1. the functioning of classic trolleybus transport supported by modern IMC solutions is an alternative to electric buses. No advantages were identified of introducing electric buses to operate the city's transport system with trolleybuses and OHL infrastructure. The advantage of IMC trolleybuses is the fact that they have relatively small on-board batteries, which in the long run affects the costs of maintenance and operation;

2. IMC technology has a positive effect on the spatial development of zero-emission transport. There is no need to build OHL in peripheral areas, with low population density or in places where it is not possible to build it, so this has a positive effect on the economic balance and offers access to electrified transport for most of the city's inhabitants;

3. The length of the bus line section under the OHL infrastructure, which is only $20-25 \%$, makes it suitable for servicing by IMC trolleybuses;

4. in the case of the Gdynia case study, it was identified that street congestion, which takes place mainly in the city centre and on the main streets where OHL is installed, has a positive effect on the functioning of IMC trolleybuses, because a longer drive under OHL has a positive effect on the process of charging on-board batteries;

5. the optimal value of the charger power for IMC trolleybuses is $150 \mathrm{~kW}$ or $100 \mathrm{~kW}$ in the case of extension of the traction infrastructure. However, it should be assumed that a sufficient value is $150 \mathrm{~kW}$.

Author Contributions: Conceptualisation, M.B. and M.P.; methodology, M.B. and M.P.; formal analysis, M.B. and M.P.; investigation, M.P.; resources, M.P.; data curation, M.B.; writing-original draft preparation, M.B. and M.P.; visualisation, M.P.; supervision, M.P.; project administration, M.P.; funding acquisition, M.P. All authors have read and agreed to the published version of the manuscript.

Funding: The research was funded by a grant from the Polish National Science Centre (No. 2016/23/ D/HS4/03085). 
Institutional Review Board Statement: Not applicable.

Informed Consent Statement: Not applicable.

Data Availability Statement: Not applicable.

Acknowledgments: The authors would like to thank Trolleybus Transport Company in Gdynia for sharing data for the development of the method presented in the article.

Conflicts of Interest: The authors declare no conflict of interest.

\section{References}

1. Santos, G. Road transport and $\mathrm{CO}_{2}$ emissions: What are the challenges? Transp. Policy 2017, 59, 71-74. [CrossRef]

2. Zhang, R.; Fujimori, S. The role of transport electrification in global climate change mitigation scenarios. Environ. Res. Lett. 2020, 15, 034019. [CrossRef]

3. New Transport Decarbonisation Alliance for Faster Climate Action. Available online: https://unfccc.int/news/new-transportdecarbonisation-alliance-for-faster-climate-action (accessed on 11 April 2021).

4. Decarbonising Transport Initiative. Available online: https://www.itf-oecd.org/decarbonising-transport (accessed on 11 April 2021).

5. European Commission. Communication from the Commission to the European Parliament, the European Council, the Council, the European Economic and Social Committee and the Committee of the Regions, The European Green Deal, COM (2019) 640 Final; European Commission: Brussels, Belgium, 2019.

6. European Commission. Communication from the Commission to the European Parliament, the Council, the European Economic and Social Committee and the Committee of the Regions, Sustainable and Smart Mobility Strategy-Putting European Transport on Track for the Future, COM (2020) 789 Final; European Commission: Brussels, Belgium, 2020.

7. Directive 2014/94/EU of the 22 October 2014 on the Deployment of Alternative Fuels Infrastructure. Available online: https: / / eur-lex.europa.eu/legal-content/en/TXT/?uri=CELEX\%3A32014L0094 (accessed on 20 March 2021).

8. National Framework for the Policy of Development of Alternative Fuel Infrastructure. Resolution of the Council of Ministers from 29 March 2017. Available online: https:/ / www.gov.pl/attachment/c3db2c7c-adc7-4b56-9bae-be4ec1e48683 (accessed on 20 March 2021).

9. Act on Electromobility and Alternative Fuels from 11 January 2018. Journal of Laws of 2018, item 317. Available online: https:/ / isap.sejm.gov.pl/isap.nsf/download.xsp/WDU20180000317/U/D20180317Lj.pdf (accessed on 20 March 2021).

10. National Center for Research and Development. Polska na Drodze do Elektromobilności; ZDG TOR: Warsaw, Poland, 2018.

11. Wierzbowski, M.; Filipiak, I.; Łyżwa, W. Polish energy policy 2050—An instrument to develop a diversified and sustainable electricity generation mix in coal-based energy system. Renew. Sustain. Energy Rev. 2017, 74, 51-70. [CrossRef]

12. Tomaszewski, K. The Polish road to the new European Green Deal-Challenges and threats to the national energy policy. Energy Policy J. 2020, 23, 5-18. [CrossRef]

13. Zawieska, J. E-mobility in transport and climate policies of European Union and Poland. In E-Mobility: Visions and Development Scenarios; Gajewski, J., Paprocki, W., Pieriegud, J., Eds.; Coalition for Strategic Mindset: Sopot, Poland, 2017; pp. 23-39.

14. Zawieska, J.; Pieregud, J. Smart city as a tool for sustainable mobility and transport decarbonization. Transp. Policy 2018, 63, 39-50. [CrossRef]

15. Połom, M.; Wiśniewski, P. Implementing electromobility in public transport in Poland in 1990-2010. A review of experiences and evaluation of the current development directions. Sustainability 2021, 13, 4009. [CrossRef]

16. Wołek, M.; Wolański, M.; Bartłomiejczyk, M.; Wyszomirski, O.; Grzelec, K.; Hebel, K. Ensuring sustainable development of urban public transport: A case study of the trolleybus system in Gdynia and Sopot (Poland). J. Clean. Prod. 2021, 279, 123807. [CrossRef]

17. Costa, Á.; Fernandes, R. Urban public transport in Europe: Technology diffusion and market organization. Transp. Res. Part. A 2012, 46, 269-284. [CrossRef]

18. Trolley: Motion. Urban E-Mobility. Available online: https://www.trolleymotion.eu/ (accessed on 11 April 2021).

19. BVG Berlin Plans Implementation of Hybrid Trolleybuses. Available online: https:/ /www.urban-transport-magazine.com/en/ bvg-berlin-plans-implementation-of-hybrid-trolleybuses / (accessed on 11 April 2021).

20. Six Van Hool Battery-Electric Trolleybuses Headed to Pescara (Italy) with New IMC System. Available online: https://www. sustainable-bus.com/news/trolleybuses-pescara-van-hool/ (accessed on 11 April 2021).

21. Praha Chce 20 Kloubových Trolejbusů Pro Linku na Letiště. Available online: https://www.cs-dopravak.cz/2019-9-30-prahachce-20-kloubovch-trolejbus-pro-linku-na-letit/ (accessed on 10 March 2021).

22. Praha Mưže Postavit Trolejbusovou Trat' až do Miškovic, má Stavební Povolení. Available online: https:/ / zdopravy.cz/prahamuze-postavit-trolejbusovou-trat-az-do-miskovic-ma-stavebni-povoleni-75403/ (accessed on 10 April 2021).

23. Is It a Bus, Is It a Train? It's MetroNeo, the Newest Mass Transport System for Nashik. Available online: https:/ /indianexpress com/article/explained/metroneo-rail-maharashtra-nashik-transport-7171793/ (accessed on 11 April 2021).

24. Alfieri, L.; Bracale, A.; Caramia, P.; Iannuzzi, D.; Pagan, M. Optimal battery sizing procedure for hybrid trolley-bus: A real case study. Electr. Power Syst. Res. 2019, 175, 105930. [CrossRef] 
25. Bartłomiejczyk, M. Practical application of In Motion Charging: Trolleybuses service on bus lines. In Proceedings of the 2017 18th International Scientific Conference on Electric Power Engineering (EPE), Loučná nad Desnou, Czech Republic, 17-19 May 2017; pp. 676-681. [CrossRef]

26. Bartłomiejczyk, M.; Połom, M. Nowoczesna koncepcja rozwoju transportu trolejbusowego-Projekt Slide-In. Autobusy Tech. Eksploat. Syst. Transp. 2015, 7-8, 2-35.

27. Bartłomiejczyk, M.; Połom, M. Dynamic Charging of Electric Buses as a Way to Reduce Investment Risks of Urban Transport System Electrification. In TRANSBALTICA XI: Transportation Science and Technology: Proceedings of the International Conference TRANSBALTICA; Gopalakrishnan, K., Prentkovskis, O., Jackiva, I., Junevičius, R., Eds.; Springer Nature Switzerland AG: Cham, Switzerland, 2020; pp. 297-308. [CrossRef]

28. Berckmans, G.; Messagie, M.; Smekens, J.; Omar, N.; Vanhaverbeke, L.; Van Mierlo, J. Cost Projection of State of the Art Lithium-Ion Batteries for Electric Vehicles Up to 2030. Energies 2017, 10, 1314. [CrossRef]

29. Bergk, F.; Biemann, K.; Lambrecht, U.; Pütz, R.; Landinger, H. Potential of In-Motion Charging Buses for the Electrification of Urban Bus Lines. J. Earth Sci. Geotech. Eng. 2016, 6, 347-362.

30. Gao, Z.; Lin, Z.; LaClair, T.J.; Liu, C.; Li, J.-M.; Birky, A.K.; Ward, J. Battery capacity and recharging needs for electric buses in city transit service. Energy 2017, 122, 588-600. [CrossRef]

31. Lenz, E. Electric bus with IMC from Kiepe Electric: Reliable, simple and more cost effective. Fachmag. V+T Verk. Tech. 2017, 8-9.

32. Połom, M.; Bartłomiejczyk, M. Alternatywne źródła zasilania w trolejbusach-Przegląd rozwiązań stosowanych w miastach europejskich. Transp. Miej. I Reg. 2011, 8, 16-20.

33. Rogge, M.; Wollny, S.; Sauer, D.U. Fast Charging Battery Buses for the Electrification of Urban Public Transport-A Feasibility Study Focusing on Charging Infrastructure and Energy Storage Requirements. Energies 2015, 8, 4587-4606. [CrossRef]

34. Wołek, M.; Szmelter-Jarosz, A.; Koniak, M.; Golejewska, A. Transformation of Trolleybus Transport in Poland. Does In-Motion Charging (Technology) Matter? Sustainability 2020, 12, 9744. [CrossRef]

35. Hołyszko, P.; Filipek, P.Z. Estimation of the running costs of autonomous energy sources in trolleybuses. J. Ecol. Eng. 2016, 17, 101-106. [CrossRef]

36. Jeong, S.; Jang, Y.J.; Kum, D. Economic Analysis of the Dynamic Charging Electric Vehicle. IEEE Trans. Power Electron. 2015, 30, 6368-6377. [CrossRef]

37. Pietrzak, K.; Pietrzak, O. Environmental Effects of Electromobility in a Sustainable Urban Public Transport. Sustainability 2020, 12, 1052. [CrossRef]

38. Yusof, N.K.; Abas, P.E.; Mahlia, T.M.I.; Hannan, M.A. Techno-Economic Analysis and Environmental Impact of Electric Buses. World Electr. Veh. J. 2021, 12, 31. [CrossRef]

39. Klucininkas, L.; Matulevicius, J.; Martuzevicius, D. The life cycle assessment of alternative fuel chains for urban buses and trolleybuses. J. Environ. Manag. 2012, 99, 98-103. [CrossRef] [PubMed]

40. Lajunen, A. Lifecycle costs and charging requirements of electric buses with different charging methods. J. Clean. Prod. 2018, 172, 56-67. [CrossRef]

41. Potkány, M.; Hlatká, M.; Debnár, M.; Hanzl, J. Comparison of the lifecycle cost structure of electric and diesel buses. Naše More 2018, 65, 270-275. [CrossRef]

42. Sheth, A.; Sarkar, D. Life Cycle Cost Analysis for Electric vs. Diesel Bus Tansit in an Indian Scenario. Life 2019, 10, 105-115. [CrossRef]

43. Czermański, E. Economic aspects of trolleybus transport in Europe. Experiences of TROLLEY project, Central Europe Programme. J. Int. Sci. Publ. Econ. Bus. 2013, 7, 471-483.

44. Czermański, E. Analiza kosztowa wybranych systemów trolejbusowych na bazie projektu TROLLEY. Autobusy Tech. Eksploat. Syst. Transp. 2013, 14, 2063-2074.

45. Dębicka, O.; Czermański, E. The cost of trolleybus transport. In The Trolleybus as an Urban Means of Transport in the Light of the Trolley Project; Wołek, M., Wyszomirski, O., Eds.; Wydawnictwo Uniwersytetu Gdańśkiego: Gdańsk, Poland, 2013 ; pp. 90-107.

46. Pietrzak, O.; Pietrzak, K. The Economic Effects of Electromobility in Sustainable Urban Public Transport. Energies 2021, 14, 878. [CrossRef]

47. Jarzmik, M. Aktualne wymagania inwestycyjne przy budowie nowej zajezdni komunikacji miejskiej-na przykładzie Przedsiębiorstwa Komunikacji Trolejbusowej Sp. z o.o. w Gdyni. Biul. Komun. Miej. 2008, 99, 48-52.

48. Bartłomiejczyk, M.; Połom, M. The impact of the overhead line's power supply system spatial differentiation on the energy consumption of trolleybus transport: Planning and economic aspects. Transport 2017, 32, 1-12. [CrossRef]

49. Bartłomiejczyk, M.; Dombrowski, J.; Połom, M.; Wyszomirski, O. Conversion of a Diesel Engine Bus into a Trolleybus; Zakład Poligrafii Fundacji Rozwoju Uniwersytetu Gdańskiego: Gdańsk, Poland, 2012; pp. 1-82.

50. Taczanowski, J.; Kołoś, A.; Gwosdz, K.; Domański, B.; Guzik, R. The development of low-emission public urban transport in Poland. Bull. Geogr. Socio-Econ. Ser. 2018, 41, 79-82. [CrossRef]

51. Połom, M.; Turżański, B. Doświadczenia Solaris Bus \& Coach w produkcji trolejbusów. Autobusy Tech. Eksploat. Syst. Transp. 2011, $18,42-49$.

52. Połom, M.; Turżański, B.; Bartłomiejczyk, M. Produkcja i sprzedaż trolejbusów Solaris Trollino w latach 2011-2014. Autobusy Tech. Eksploat. Syst. Transp. 2015, 22, 8-12. 
53. Połom, M. International Relations on the Market of Trolleybus' Manufacturers in Europe in the Years 2000-2014. Stud. Ind. Geogr. Comm. Pol. Geogr. Soc. 2016, 30, 75-90.

54. Bedell, R. A Practical, 70-90\% Electric Bus without Overhead Wires. In Proceedings of the EVS24 Conference, Stavanger, Norway, 13-16 May 2009; pp. 1-7.

55. Brdulak, A.; Chaberek, G.; Jagodziński, J. Development Forecasts for the Zero-Emission Bus Fleet in Servicing Public Transport in Chosen EU Member Countries. Energies 2020, 13, 4239. [CrossRef]

56. Krawiec, S.; Łazarz, B.; Markusik, S.; Karoń, G.; Sierpiński, G.; Krawiec, K. Urban public transport with the use of electric buses-development tendencies. Transp. Probl. 2016, 11, 127-137. [CrossRef]

57. Kühne, R. Electric buses-An energy efficient urban transportation means. Energy 2010, 35, 4510-4513. [CrossRef]

58. Bogusławski, J. Gdynia rozbudowuje sieć trolejbusową. Transp. Miej. I Reg. 2006, 1, 27-31.

59. Brunton, L.J. Why not the trolleybus. In Electric, Hybrid and Fuel Cell Vehicles; IEEE Seminar: 5/1-5/7; IET: Durham, UK, 2000.

60. Göhlich, D.; Fay, T.-A.; Jefferies, D.; Lauth, E.; Kunith, A.; Zhang, X. Design of urban electric bus systems. Des. Sci. 2018, 4, 1-28. [CrossRef]

61. Tsolas, I.E. Performance Evaluation of Electric Trolley Bus Routes. A Series Two-Stage DEA Approach. Infrastructures 2021, 6, 44. [CrossRef]

62. Borowik, L.; Cywiński, A. Modernization of a trolleybus line system in Tychy as an example of eco-efficient initiative towards a sustainable transport system. J. Clean. Prod. 2016, 117, 188-198. [CrossRef]

63. Połom, M. Projekt rewitalizacji i rozwoju komunikacji trolejbusowej w Gdyni współfinansowany ze środków unijnych. Transp. Miej. I Reg. 2011, 6, 25-30.

64. Hebel, K. Kierunki rozwoju komunikacji trolejbusowej w świetle wyników badań marketingowych w Gdyni. Logistyka 2012, 3 , 787-792.

65. Jagiełło, A.; Gałka, P. Impact of changes in organization of trolleybus line no. 29 in Gdynia on passangers' travel behavior. Transp. Econ. Logist. 2017, 70, 109-117. [CrossRef]

66. Biresselioglu, M.E.; Kaplan, M.D.; Yilmaz, B.K. Electric mobility in Europe: A comprehensive review of motivators and barriers in decision making processes. Transp. Res. Part A 2018, 109, 1-13. [CrossRef]

67. Cansino, J.M.; Sánchez-Braza, A.; Sanz-Díaz, T. Policy Instruments to Promote Electro-Mobility in the EU28: A Comprehensive Review. Sustainability 2018, 10, 2507. [CrossRef]

68. Chertkovskaya, E.; Paulsson, A. The end of the line: Envisioning degrowth and ecosocial justice in the resistance to the trolleybus dismantlement in Moscow. Local Environ. 2021, 1-19. [CrossRef]

69. Dyr., T. Wsparcie rozwoju transportu publicznego z funduszy strukturalnych w pierwszym okresie członkostwa Polski w Unii Europejskiej. Transp. Miej. I Reg. 2006, 9, 2-10.

70. Khorovitch, B. The trolleybus in a modern city: State-of-the-art and future perspectives. Public Transp. Int. 2004, $53,53-57$.

71. Kołoś, A.; Taczanowski, J. Fundusze europejskie jako czynnik rozwoju miejskiego transportu szynowego w Polsce. Pr. Kom. Geogr. Komun. Ptg 2016, 19, 9-20. [CrossRef]

72. Krawiec, S.; Krawiec, K. Rozwój elektromobilności w Polsce. Uwarunkowania, cele i bariery. Zesz. Nauk. Uniww. Ekon. W Katowicach 2017, 332, 17-21.

73. Lejda, K.; Mądziel, M.; Siedlecka, S.; Zielińska, E. The future of public transport in light of solutions for sustainable transport development. Sci. J. Sil. Univ. Technol. Ser. Transp. 2017, 95, 97-108. [CrossRef]

74. Mathieu, L. Electric Buses Arrive on Time-Marketplace, Economic, Technology, Environmental and Policy Perspectives for Fully Electric Buses in the EU; European Federation for Transport and Environment: Brussels, Belgium, 2018.

75. Pejšova, M. Environmentally Friendly Public Transport. Trans. Transp. Sci. 2014, 7, 153-160. [CrossRef]

76. Perujo, A.; Van Grootveld, G.; Scholz, H. Present and Future Role of Battery Electrical Vehicles in Private and Public Urban transport. In New Generation of Electric Vehicles; Stevic, Z., Ed.; InTech: Rijeka, Croatia, 2012; pp. 3-25.

77. Petkov, D. The uneven development path of Bulgarian trolleybus transport-Leading back to the future? Case Stud. Transp. Policy 2020, 8, 1383-1392. [CrossRef]

78. Połom, M. Przemiany Funkcjonowania Komunikacji Trolejbusowej w Polsce w Latach 1989-2013; Wydawnictwo Bernardinum: Pelplin, Poland, 2019; pp. 1-284.

79. Rădulescu, V.; Străinescu, I.; Moroianu, L.; Tudor, E.; Gheorghe, S.; Goia, C. Urban electrical vehicles as the solution for public transportation in the cities of Romania. Urban Transp. 2011, XVII, 449-458.

80. Tucki, K.; Orynycz, O.; Świć, A.; Mitoraj-Wojtanek, M. The Development of Electromobility in Poland and EU States as a Tool for Management of $\mathrm{CO}_{2}$ Emissions. Energies 2019, 12, 2942. [CrossRef]

81. Wołek, M. Transport trolejbusowy w kształtowaniu zrównoważonej mobilności miejskiej na przykładzie Gdyni. Autobusy Tech. Eksploat. Syst. Transp. 2013, 7-8, 42-46.

82. Brazis, V.; Latkovskis, L.; Grigans, L. Simulation of trolleybus traction induction drive with supercapacitor energy storage system. Latv. J. Phys. Tech. Sci. 2010, 47, 33-47. [CrossRef]

83. Hutyria, S.; Chanchin, A.; Yaglinskyi, V.; Khomiak, Y.; Popov, V. Evolution of trolley-bus: Directions, indicators, trends. Diagnostyka 2020, 21, 11-26. [CrossRef]

84. Krawiec, K. Proces wprowadzania autobusów elektrycznych do eksploatacji w przedsiębiorstwach komunikacji miejskiejwybrane zagadnienia. Pr. Nauk. Politech. Warsz. 2016, 112, 217-226. 
85. Molecki., A. Zasilanie liniowe w aspekcie rozwoju branży autobusów elektrycznych. Autobusy Tech. Eksploat. Syst. Transp. 2018, 7-8, 28-32. [CrossRef]

86. Paul, T.; Yamada, H. Operation and charging scheduling of electric buses in a city bus route network. In Proceedings of the 17th International IEEE Conference on Intelligent Transportation Systems (ITSC), Qingdao, China, 8-11 October 2014; pp. $2780-2786$. [CrossRef]

87. An Updated Overview of Electric Buses in Europe; ZeEUS eBus Report \#2; Zero Emission Urban Bus System: Brussels, Belgium, 2018.

88. Pacuk, M.; Anisiewicz, R.; Czochański, J.; Kopeć, K.; Połom, M.; Michalski, T.; Tarkowski, M. Gdynia w Unii Europejskiej. Warunki Życia; Wydawnictwo Bernardinum: Pelplin, Poland, 2016; pp. 1-211.

89. Połom, M. European Union Funds as a Growth Stimulant of Electromobility on the Example of Electric Public Transport in Poland. Barom. Reg. Anal. I Progn. 2015, 13, 89-96.

90. Połom, M.; Palmowski, T. Rozwój i Funkcjonowanie Komunikacji Trolejbusowej w Gdyni; Wydawnictwo Bernardinum: Pelplin, Poland, 2009; pp. 1-152.

91. Połom, M.; Bartłomiejczyk, M. Promocja elektrycznego transportu miejskiego. Projekt Trolley. Autobusy Tech. Eksploat. Syst. Transp. 2011, 12, 42-45.

92. Rulaff, M. Projekt Trolley jako przykład promowania ekologicznego transportu zbiorowego. Zesz. Nauk. Politech. Poznańskiej. Organ. I Zarz. 2013, 60, 89-96.

93. Wołek, M. Projekt TROLLEY jako platforma współpracy środowisk transportowych w Europie Środkowo-Wschodniej. Autobusy Tech. Eksploat. Syst. Transp. 2012, 13, 16-18.

94. Połom, M. Trends in the development of trolleybus transport in Poland at the end of the second decade of the 21st century. Pr. Kom. Geogr. Komun. Ptg 2018, 21, 44-59. [CrossRef] 